This report was prepared as an account of work sponsored by an agency of the United States

Government. Neither the United States Government nor any agency thereof, nor any of their employees, makes any warranty, express or implied, or assumes any legal liability or responsibility for the accuracy, completeness, or usefulness of any information, apparatus, product, or process disclosed, or represents that its use would not infringe privately owned rights. Reference herein to any specific commercial product, process, or service by trade name, trademark, manufacturer, or otherwise does not necessarily constitute or imply its endorsement, recommendation, or favoring by the United States Government or any agency thereof. The views and opinions of authors expressed herein do not necessarily state or reflect those of the United States Government or any agency thereof.

\title{
National Institutes of Health: Mixed Waste Stream Analysis
}

\author{
N. P. Kirner \\ G. P. Faison \\ D. R. Johnson
}

Published August 1994

\section{Idaho National Engineering Laboratory EG\&G Idaho, Inc. Idaho Falls, Idaho 83415}

Prepared for EG\&G Idaho, Inc. Under Subcontract No. C90-132744 and for the

U.S. Department of Energy Assistant Secretary for Environmental Management Contract DE-AC07-76ID01570 DISTRIBUTION OF THIS DOCUMENT IS UNLIMITE 


\section{DISCLAIMER}

Portions of this document may be illegible in electronic image products. Images are produced from the best available original document. 


\begin{abstract}
This report presents the methodology and findings of a technical analysis conducted on the many biomedical mixed waste streams generated by the National Institutes of Health (NIH) that are believed to be representative of the biomedical mixed waste community. The analysis included the characterization of the mixed waste streams based on information contained in an NIH mixed waste management database; the report combines the characterization information into similar process categories. The resulting information will help define and characterize the mixed waste streams generated by the biomedical community so that an identification can be made of the waste streams that can and cannot be minimized and treated by current options.
\end{abstract}




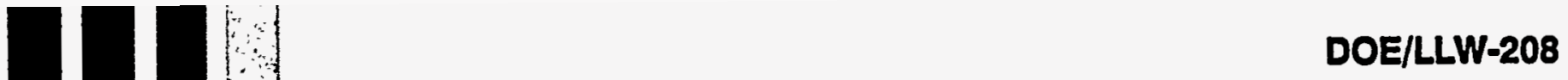

PECENED

OCT 271995

OSTI

\section{National Institutes of Health: Mixed Waste Stream Analysis}

\section{National Low-Level Waste Management Program}

August 1994

DIGTRIBUTION OF THIS DOCUMENT IS UNLIMITED 
This report was prepared as an account of work sponsored by an agency of the United States Government. Neither the United States Government nor any agency thereof, nor any of their employees, makes any warranty, express or implied, or assumes any legal liability or responsibility for the accuracy, completeness, or usefulness of any information, apparatus, product, or process disclosed, or represents that its use would not infringe privately owned rights. Reference herein to any specific commercial product, process, or service by trade name, trademark, manufacturer, or otherwise does not necessarily constitute or imply its endorsement, recommendation, or favoring by the United States Government or any agency thereof. The views and opinions of authors expressed herein do not necessarily state or reflect those of the United States Government or any agency thereof.

\title{
National Institutes of Health: Mixed Waste Stream Analysis
}

\author{
N. P. Kirner \\ G. P. Faison \\ D. R. Johnson
}

Published August 1994

\section{Idaho National Engineering Laboratory EG\&G Idaho, Inc. Idaho Falls, Idảho 83415}

Prepared for EG\&G Idaho, Inc.

Under Subcontract No. C90-132744

and for the

U.S. Department of Energy

Assistant Secretary for Environmental Management

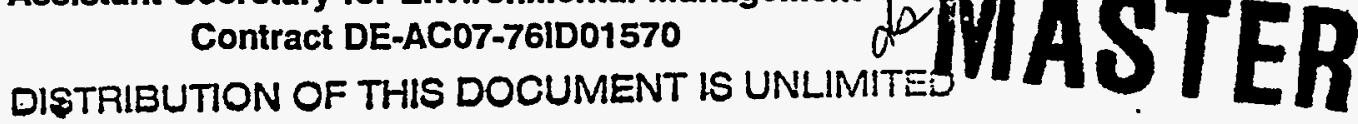




\section{CONTENTS}

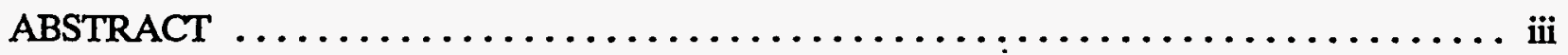

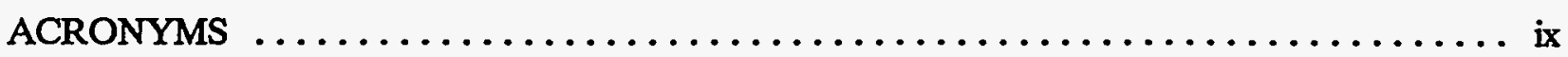

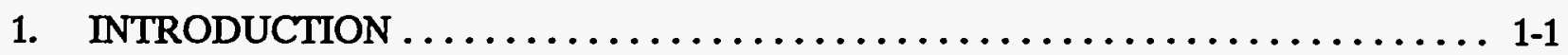

$1.1 \quad$ Background and Purpose $\ldots \ldots \ldots \ldots \ldots \ldots \ldots \ldots \ldots \ldots \ldots \ldots \ldots \ldots \ldots \ldots \ldots .1$

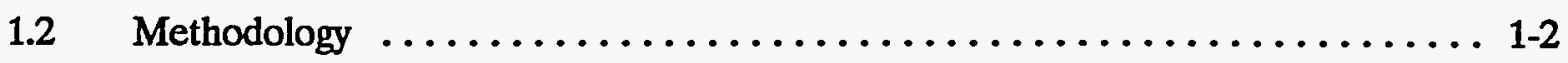

1.2.1 Preliminary Analyses $\ldots \ldots \ldots \ldots \ldots \ldots \ldots \ldots \ldots \ldots \ldots \ldots \ldots \ldots . .2$

1.2.2 Subtask 1-Identify Processes Responsible for Waste Generation .... 1-2

1.2.3 Subtask 2-Combine Similar Processes ................ 1-3

1.2.4 Subtask 3-Segregate Waste Streams Generated by One-time Operations ...................... 1-3

1.2.5 Subtask 4-Assemble Detailed Waste Stream Characterizations ..... 1-3

1.2.6 Subtask 5-Identify and Categorize Mixed Waste Streams for Which No Current Treatment/Disposal Options are Available ...... 1-3

1.2.7 Development of Final Report ................... 1-3

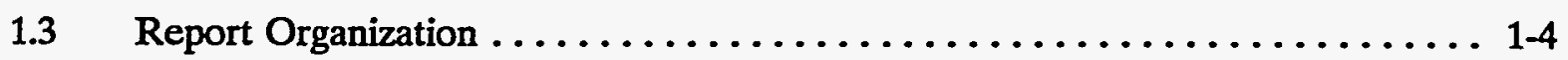

2. IDENTIFICATION AND COMBINATION OF THE PROCESSES RESPONSIBLE FOR WASTE GENERATION $\ldots \ldots \ldots \ldots \ldots \ldots \ldots \ldots \ldots \ldots .2-1$

2.1 Description of Waste Generating Processes $\ldots \ldots \ldots \ldots \ldots \ldots \ldots \ldots .2-2$

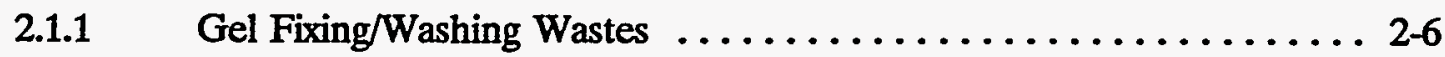

2.1.2 High-Performance Liquid Chromatography

Scintillation Counting Fluids $\ldots \ldots \ldots \ldots \ldots \ldots \ldots \ldots \ldots \ldots, 2-6$

2.1.3 Filter/Blot Washing $\ldots \ldots \ldots \ldots \ldots \ldots \ldots \ldots \ldots \ldots \ldots \ldots \ldots \ldots \ldots \ldots \ldots, 2-7$

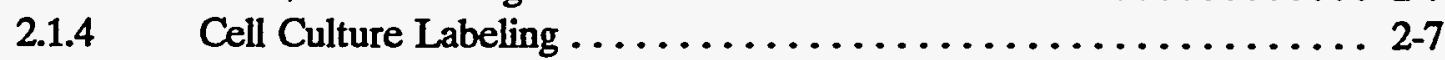

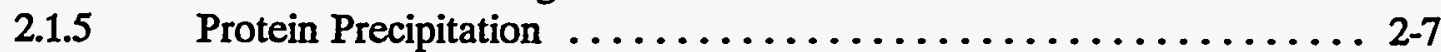

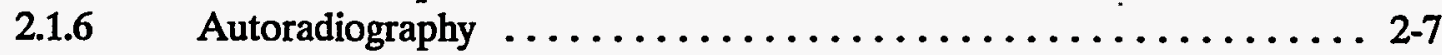

2.1.7 Radioimmunoassay ...........................

$2.2 \quad$ Supplemental Mixed Waste Streams $\ldots \ldots \ldots \ldots \ldots \ldots \ldots \ldots \ldots \ldots \ldots .2-8$

3. DESCRIPTION OF WASTE STREAMS GENERATED BY

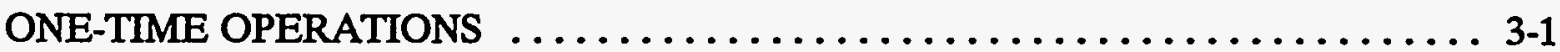

4. WASTE STREAM CHARACTERIZATIONS OF THE

WASTE GENERATING PROCESSES 
5. IENTIFICATION AND CATEGORIZATION OF WASTE STREAMS

WTTH LIMITED TREATMENT/DISPOSAL OPTIONS

6. CONCLUSIONS $\ldots \ldots \ldots \ldots \ldots \ldots \ldots \ldots \ldots \ldots \ldots \ldots \ldots \ldots \ldots \ldots \ldots$

7. REFERENCES $\ldots \ldots \ldots \ldots \ldots \ldots \ldots \ldots \ldots \ldots \ldots \ldots \ldots \ldots \ldots \ldots \ldots \ldots$

8. CONTACTS $\ldots \ldots \ldots \ldots \ldots \ldots \ldots \ldots \ldots \ldots \ldots \ldots \ldots \ldots \ldots \ldots \ldots \ldots$

\section{FIGURES}

2-1. Distribution of waste volume by process for containerized mixed waste generated at $\mathrm{NIH}$

5-1. Distribution of waste volume by process for waste with disposal options. . . . . . 5-19

5-2. Distribution of waste volume by process for waste in process at NIH $\ldots \ldots \ldots . . .5-20$

5-3. Distribution of waste volume by process for waste with no disposal options. . . . . . 5-21

\section{TABLES}

2-1. Volume of NIH mixed waste by process category $\ldots \ldots \ldots \ldots \ldots \ldots \ldots \ldots$

2-2. Volume of supplemental mixed wastes disposed of by NIH $\ldots \ldots \ldots \ldots \ldots \ldots$

3-1. Summary of one-time waste generating processes at the NIH $\ldots \ldots \ldots \ldots \ldots . \ldots 3-2$

4-1. Chemical properties of $\mathrm{NIH}$ mixed waste $\ldots \ldots \ldots \ldots \ldots \ldots \ldots \ldots \ldots \ldots \ldots$

4-2. Chemicals typically present in $\mathrm{NIH}$ mixed waste $\ldots \ldots \ldots \ldots \ldots \ldots \ldots \ldots$

4-3. Typical EPA hazardous waste numbers for $\mathrm{NIH}$ mixed waste $\ldots \ldots \ldots \ldots \ldots \ldots$

4-4. Radiological properties of NIH mixed waste $\ldots \ldots \ldots \ldots \ldots \ldots \ldots \ldots \ldots$

4-5. Radiological properties of supplemental NIH mixed waste $\ldots \ldots \ldots \ldots \ldots \ldots \ldots$

5-1. Chemical properties of NIH mixed waste with no disposal options $\ldots \ldots \ldots \ldots . \ldots 5-2$

5-2. Chemicals typically present in NIH mixed waste with no disposal options ........ 5-3

5-3. Typical EPA hazardous waste numbers for NIH mixed waste with no disposal options $\ldots \ldots \ldots \ldots \ldots \ldots \ldots \ldots \ldots \ldots \ldots \ldots \ldots \ldots \ldots$

5-4. Radiological properties of NIH mixed waste with no disposal options . . . . . . . 5-7 
5-5. Chemical properties of NIH mixed waste in process $\ldots \ldots \ldots \ldots \ldots \ldots \ldots \ldots \ldots$

5-6. Chemicals typically present in NIH mixed waste in process $\ldots \ldots \ldots \ldots \ldots \ldots \ldots$

5-7. Typical EPA hazardous waste numbers for $\mathrm{NIH}$ mixed waste in process $\ldots \ldots \ldots \ldots 5-12$

5-8. Radiological properties of NIH mixed waste in process $\ldots \ldots \ldots \ldots \ldots \ldots \ldots \ldots$

5-9. Volume of NIH mixed waste by handling steps $\ldots \ldots \ldots \ldots \ldots \ldots \ldots \ldots \ldots \ldots \ldots$ 


\section{ACRONYMS}

ATP $\quad$ Adenosine triphosphate

DNA Deoxyribonucleic acid

DOE U.S. Department of Energy

EPA U.S. Environmental Protection Agency

HPLC High performance liquid chromatography

LLW Low-level radioactive waste

LLRWPA Low-Level Radioactive Waste Policy Act of 1980

NIH National Institutes of Health

NLLWMP National Low-Level Waste Management Program

RCRA Resource Conservation and Recovery Act

RNA Ribonucleic acid 


\section{National Institutes of Health: Mixed Waste Stream Analysis}

\section{INTRODUCTION}

\subsection{Background and Purpose}

The Low-Level Radioactive Waste Policy Amendments Act of 1985 requires that the U.S. Department of Energy (DOE) provide technical assistance to host States, compact regions, and unaffiliated States to fulfill their responsibilities under the Act. The National Low-Level Waste Management Program (NLLWMP) operated for DOE by EG\&G Idaho, Inc. provides technical assistance in the development of new commercial low-level radioactive waste disposal capacity.

The NLLWMP has been requested by the Appalachian Compact to help the biomedical community become better acquainted with its mixed waste streams, to help minimize the mixed waste streams generated by the biomedical community, and to provide applicable treatment technologies to those particular mixed waste streams. Mixed waste is waste that satisfies the definition of low-level radioactive waste (LLW) in the Low-Level Radioactive Waste Policy Act of 1980 (LLRWPA) and contains hazardous waste that either (a) is listed as a hazardous waste in Subpart D of 40 CFR 261, or (b) causes the LLW to exhibit any of the hazardous waste characteristics identified in 40 CFR 261.

The purpose of this report is to clearly define and characterize the mixed waste streams generated by the biomedical community so that an identification can be made of the waste streams that can and cannot be minimized and treated by current options. An understanding of the processes and complexities of generation of mixed waste in the biomedical community may encourage more treatment and storage options to become available.

Specifically, the report includes a technical analysis of the many biomedical mixed waste streams generated by the National Institutes of Health (NIH) that are believed to be representative of the biomedical mixed waste community.

The NIH has numerous processes that generate mixed wastes. The NIH has created a detailed database for use in tracking the low-level radioactive containerized mixed waste generated by these processes. This database contains detailed information on waste origination, hazardous waste numbers, chemical properties, radionuclide assays, waste volume, waste generation processes, treatment processes used on the wastes, and waste storage, shipping, and handling requirements. The database is maintained using dBASE IV and contains approximately 3,800 records.

In addition to the containerized mixed waste that is tracked by the database, there are two supplemental mixed waste streams that were not included in the database as of July 1993. These two supplemental waste streams are tracked outside of the database based on their properties, 
waste stream size, and methods of handling and disposal. The supplemental mixed waste is discussed further in Section 2.2 and Section 4.

\subsection{Methodology}

\subsubsection{Preliminary Analyses}

Ebasco Environmental performed a preliminary analysis of mixed waste streams using the database maintained by the NIH. The database received from NIH is in a dBASE IV format and contains 17 database groups within a "mixed waste" catalog. The 17 databases contain approximately 4,000 records dating from 1989 through June 1993. In most cases, one database record was created for each waste container received by the waste management group at NIH. Three of the 17 databases contain the majority of the database records. The waste management group at NIH uses the 17 individual database groups to track the waste through the waste handling steps in the NIH waste management process and to separate the database information according to chronological period and container number.

The 17 databases used for the analysis contain records with a total of 187 fields each. The field identifiers used in the records required some clarification for the databases as received. A detailed list of questions was prepared and forwarded to NIH for the fields that were subject to variable interpretation. NIH responded with information that was used to clarify the interpretation of the fields. Copies of these communications were included in an earlier letter report to EG\&G Idaho, Inc. on August 27, 1993. Ebasco Environmental personnel also participated in a tour of the NIH Building 21 waste processing area that was conducted by NIH staff. Procedures for mixed waste acceptance, management, and disposal were outlined, as well as use and maintenance of the database.

The NIH database information was used to group the waste streams into process groups that appeared to be derived from similar activities. The processes were grouped based on a comparison of the descriptions of the waste generating processes provided for each container of mixed waste in the database. The groups were used to identify the major process sources and develop characterizations of the waste produced. Preliminary information was developed and presented to the Biomedical Mixed Waste Workshop held in Bethesda, Maryland, on August 4 and 5,1993 . Some of the key preliminary findings were (a) relatively few waste generating processes produced the large majority of the waste, and (b) wastes produced by these processes have similar properties and compositions.

\subsubsection{Subtask 1-Jdentify Processes Responsible for Waste Generation}

A waste generating process was identified for each of the database records in two sequential fields containing a total of 128 characters. Generally, the process descriptions consisted of less than 10 words and were therefore somewhat cryptic. A problem with this data was that the descriptive words for the waste generating processes varied between records from what appeared to be similar processes. This created some difficulty in extracting and comparing the process data.

This difficulty was overcome by using key words for each process group to identify records, which described waste that appeared to originate from each of the particular process groups. 
When the key word was found in the process description, the record was selected for inclusion in the process group. Section 2 presents the waste generating process groups that were identified in this way.

\subsubsection{Subtask 2-Combine Similar Processes}

After the waste generating processes had been identified, similar processes were combined based on similar process activities. Wastes were grouped into 31 similar process categories, based on database information, and one unknown category. These 32 categories are used throughout the report for analytical purposes.

\subsubsection{Subtask 3-Segregate Waste Streams Generated by One-time Operations}

"One-time" waste streams were those waste streams that were produced relatively infrequently with properties and compositions that were markedly dissimilar from other waste streams. The process description information and the waste composition and waste properties data were used to identify these streams. The results from Subtasks 1 and 2 were used to identify and characterize the one-time waste streams. The one-time wastes are discussed in Section 3.

\subsubsection{Subtask 4-Assemble Detailed Waste Stream Characterizations}

The process information, waste composition data, and waste properties data developed in Subtasks 1 and 2 were used to develop the waste stream characterization for each of the waste generating processes. The available data limited the degree of detail that could be provided for the waste characterization. The characterizations are limited to radioassay parameters, $\mathrm{pH}$, flashpoint, chemical composition data, and U.S. Environmental Protection Agency (EPA) hazardous waste codes. Section 4 presents this information.

\subsubsection{Subtask 5-Identify and Categorize Mixed Waste Streams for Which No Current Treatment/Disposal Options are Available}

Information was available in the NIH database for treatment and disposal options that have been used for the mixed wastes generated at NIH. This information was combined with information developed in Subtask 4 to identify the waste streams that do not have current treatment and disposal options. This information was used to categorize the waste according to treatment and disposal options. Section 5 includes a discussion of this information.

\subsubsection{Development of Final Report}

The preparation of the final report required that the five subtasks be completed for all of the information from the databases. Essentially, the required data from each of the databases were combined into a focused database that was then used to complete the analyses of the data required to complete the subtasks. The fields used in this final analysis were primarily the process description, waste volume, generator location, radioassay information, physical properties of $\mathrm{pH}$ and flashpoint, waste composition data, and the Resource Conservation and Recovery Act (RCRA) hazardous waste codes. This report presents the results of the analysis. 


\subsection{Report Organization}

Information on the waste generating processes is presented in Section 2 along with the results of an analysis of the waste volume produced by each of the main process groups. Section 3 presents information on the one-time processes that have produced mixed waste. Detailed characterization information by process group is presented on the waste streams in Section 4. Additional detailed information is provided in Section 5 on waste streams that apparently have no current treatment and disposal options. Section 6 presents the conclusions of the analysis and briefly describes the subsequent steps in a waste minimization process. 


\section{IDENTIFICATION AND COMBINATION OF THE PROCESSES RESPONSIBLE FOR WASTE GENERATION}

Radioactively labeled chemicals are widely used in biomedical research to trace the movement of substances through analytical equipment and processes and through biological processes. Technical information about the use of radioactively labeled substances in biomedical research was obtained from references listed at the end of this document. The NIH performs biomedical research activities in many different areas using radioactively labeled chemicals and generates mixed waste from a variety of biochemical research techniques. This section presents a brief overview of these research activities and discusses the interrelationships of the waste generation activities.

The NIH provides a centralized waste management group that is responsible for properly treating, storing, recording, and disposing of all wastes generated at NIH. As part of this responsibility, the waste management group maintains a detailed database on each radioactive and hazardous waste container generated at the NIH. The NIH mixed waste database contains information for the containerized mixed waste received by the waste management group between early 1989 and June 1993 and contains approximately 3,800 records for this period. However, as noted previously, this database does not include data on two supplemental mixed waste streams that are discussed in Section 2.2. The database was set up with a very large number of fields to provide the flexibility necessary to systematically document all of the waste management activities for the mixed wastes. A total of 187 fields were created for each record in the database and, in most cases, one record had been created for each container of waste received at the NIH. A supporting waste tracking system is used at the NIH to gather and enter the data into the database as they become available during the waste management activities.

The NIH waste tracking system begins with the generation of waste at one of the many laboratory and research facilities at the NIH. The facility that is generating the waste contacts the waste management group and completes a waste tracking form for each container of waste that is being generated. The waste tracking form requires the generator to provide complete process and waste composition information. The waste management group then collects the waste and transports it to the waste management building. Liquid wastes are then sampled and tested for $\mathrm{pH}$ and flashpoint. A radioassay is performed on the waste that indicates the activity of the radionuclides found to be present. The results of this analytical testing and the information provided on the waste tracking form are entered into the NIH database. A determination is made of the regulatory status and classification of the waste and of the treatment and disposal options available for the waste. The waste then moves through the NIH waste management system based on this determination and is tracked by the waste management group using the computer database.

Because of the complexity of the research activities at the NIH, the information on the process that was used to generate the waste must, by necessity, be provided by the generator. This is because the research activities can be varied, unpredictable, and at the forefront in using heretofore unknown procedures. In the past, the generators have tended to provide very limited and general information about the waste generating activities. This information is entered into 
the database in two character fields, each with a length of 76 characters. For most of the records, however, the information entered is sufficiently limited so that only one field is required.

The processes used for waste generation at the NIH were primarily characterized for this study by using key words contained in the process description field. The key words were extracted from the field, grouped according to apparent process similarities, and then sorted and combined to develop groupings of similar activities that seemed to be from similar waste generating processes. Thirty-two process groupings were ultimately developed in this way. These process groups were then used throughout the remainder of the report to analyze and track the waste management activities. Most of these 32 groupings seem to represent unique and distinct process activities. Nonetheless, several of the groups may be subsets of other groups. These subsets could not be combined, however, based on the information available. For example, a significant portion of the waste contains general information such as "radioassay" and is therefore not specific enough to include into one of the more specific process groups. Some of the 32 groupings represent groupings of processes that are dissimilar. An example would be deoxyribonucleic acid/ribonucleic acid (DNA/RNA) extractions/sequencing. While the extraction and sequencing activities are distinct, there appear to be sufficient similarities to justify combining them as a single process group. This method of combining was also used for the gel fixing/washing and staining/destaining processes. For another significant portion of the data, the process information provided is incomplete or lacking and cannot be used to assign the waste to one of the process groups. Generally, this waste is some of the older waste and obtaining detailed information from the generator as the program was being initiated was probably difficult. Waste with incomplete. process information is grouped in an "unknown" category.

Figure 2-1 graphically depicts the relative volumes of the containerized mixed wastes received at the NIH in 21 of the largest process groups. This figure does not include the two supplemental mixed waste streams that are described in Section 2.2. The remaining 11 process groups contain a relatively small amount of waste and are grouped as "all others." Table 2-1 lists the waste volume for each of the 32 waste generating processes and lists the relative percentages of each process. As Table 2-1 shows, $67 \%$ of the waste is produced by the three largest processes and over $90 \%$ of the waste volume is produced by the 10 largest processes. A brief discussion of the largest waste generating processes is presented below. Table 2-2 contains the waste volumes generated for the two supplemental mixed waste streams.

\subsection{Description of Waste Generating Processes}

The mixed waste generating processes at NIH are highly specialized and complex research techniques that are used by researchers to investigate specific areas of interest. The development of such research techniques is an ongoing process that results in large changes in the procedures in a relatively short period of time. Therefore, any discussion of the processes and techniques used is likely to become quickly dated. A large variety of such processes is used at the NIH as a part of its research activities. However, the analysis of the mixed waste database indicates that most of the processes are variations of a few research techniques and that these techniques produce the majority of the total mixed waste volume. Following are brief and simplified discussions of these research processes that describe the techniques in a general way, but do not represent the full scope and scale of research activities at the NIH. Researchers at the NIH are at the forefront of developing improved biochemical techniques and procedures and are 


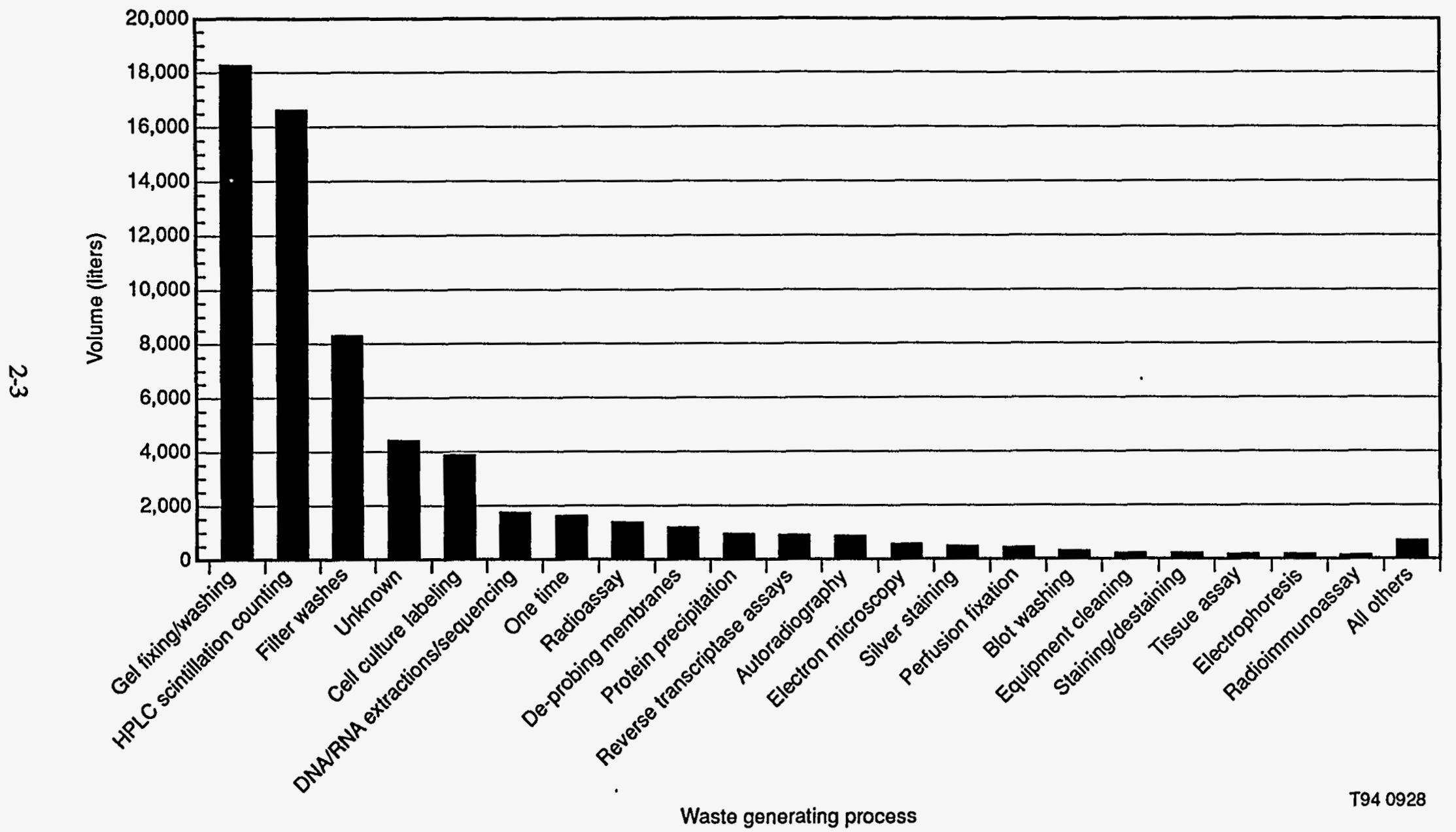

Figure 2-1. Distribution of waste volume by process for containerized mixed waste generated at NIH. 
Table 2-1. Volume of NIH mixed waste by process category.

\begin{tabular}{|c|c|c|c|c|}
\hline Waste generating process & $\begin{array}{l}\text { Contents } \\
\text { volume } \\
\text { (L) }\end{array}$ & $\begin{array}{l}\text { Container } \\
\text { volume } \\
\text { (L) }\end{array}$ & $\begin{array}{l}\text { Contents } \\
\text { volume percent } \\
\text { of total }\end{array}$ & $\begin{array}{c}\text { Cumulative } \\
\text { percent }\end{array}$ \\
\hline Gel fixing/washing & 18,201 & 20,054 & 28.4 & 28.4 \\
\hline HPLC scintillation counting & 16,614 & 18,396 & 25.9 & 54.3 \\
\hline Filter washes & 8,261 & 9,230 & 12.9 & 67.2 \\
\hline Unknown & 4,342 & 5,392 & 6.8 & 73.9 \\
\hline Cell culture labeling & 3,913 & 4,798 & 6.1 & 80.0 \\
\hline DNA/RNA extractions/sequencing & 1,793 & 2,070 & 2.8 & 82.8 \\
\hline One-time processes & 1,652 & 1,491 & 2.6 & 85.4 \\
\hline Radioassay & 1,344 & 1,582 & 2.1 & 87.5 \\
\hline Deprobing membranes & 1,209 & 1,336 & 1.9 & 89.4 \\
\hline Protein precipitation & 1,010 & 1,200 & 1.6 & 90.9 \\
\hline Reverse transcriptase assays & 990 & 1,040 & 1.5 & 92.5 \\
\hline Autoradiography & 852 & 1,020 & 1.3 & 93.8 \\
\hline Electron microscopy & 601 & 714 & 0.9 & 94.8 \\
\hline Silver staining & 508 & 468 & 0.8 & 95.5 \\
\hline Perfusion fixation & 453 & 486 & 0.7 & 96.3 \\
\hline Blot washing & 349 & 772 & 0.5 & 96.8 \\
\hline Equipment cleaning & 344 & 396 & 0.5 & 97.3 \\
\hline Staining/destaining & 292 & 305 & 0.5 & 97.8 \\
\hline Tissue assay & 223 & 313 & 0.3 & 98.1 \\
\hline Electrophoresis & 223 & 246 & 0.3 & 98.5 \\
\hline Radioimmunoassay & 161 & 180 & 0.3 & 98.7 \\
\hline Operating room wastes & 156 & 156 & 0.2 & 99.0 \\
\hline Tissue staining & 149 & 170 & 0.2 & 99.2 \\
\hline Cancer treatment & 101 & 101 & 0.2 & 99.4 \\
\hline Cell assays & 95 & 131 & 0.1 & 99.5 \\
\hline Lipid extraction & 88 & 106 & 0.1 & 99.7 \\
\hline ATP extractions & 56 & 60 & 0.1 & 99.7 \\
\hline Phosphorylation & 50 & 52 & 0.1 & 99.8 \\
\hline Membrane washing & 42 & 68 & 0.1 & 99.9 \\
\hline Protein harvesting & 34 & 64 & 0.1 & 99.9 \\
\hline Hormonal labeling & 31 & 41 & 0.0 & 100.0 \\
\hline Automated amino assay & 12 & 20 & 0.0 & 100.0 \\
\hline Total & 64,146 & 72,458 & 100.0 & \\
\hline \multicolumn{5}{|c|}{$\begin{array}{ll}\text { HPLC } & =\text { high-performance liquid chromatography } \\
\text { DNA/RNA } & =\text { deoxyribonucleic acid/ribonucleic acid } \\
\text { ATP } & =\text { adenosine triphosphate. }\end{array}$} \\
\hline
\end{tabular}


Table 2-2. Volume of supplemental mixed wastes disposed of by NIH.

Number of
containers
shipped for
disposal

Liquid scintillation vials

1986

1987

1988

1989

1990

1991

1992

1993 (Jan.-June)

Total

Solid medical pathological waste ${ }^{\mathrm{a}}$

Vials with mercury/ ${ }^{3} \mathrm{H}$
1,212

987

931

850

829

733

612

255

220

25
Shipping container volume

(L)

Volume shipped

(L)

$212 \quad 257,392$

212

209,609

212

197,716

212

180,515

212

176,055

212

155,667

212

129,970

212

54,154

$1,361,078$
74
46,721

$0.005-0.5$

0.81

a. Solid medical pathological waste is contaminated with cytotoxic agents (melphalan), thus making it a mixed waste. 
continuously striving to develop completely new techniques while improving the capabilities of existing ones.

\subsubsection{Gel Fixing/Washing Wastes}

Gel electrophoresis is a valuable tool for effecting separations of protein or DNA/RNA fragments and is often used to determine the sequence of peptides in a protein or bases in nucleic acids. In this technique, DNA, RNA, or a protein is labeled with nuclides such as ${ }^{32} \mathrm{P}$ or ${ }^{35} \mathrm{~S}$ and is broken up into fragments. The mixture of fragments is then placed on a gel where separation occurs due to the differential rates of migration of the fragments across and through the gel medium. After the separation has progressed sufficiently, the gel is "fixed" or washed with solvents such as methanol to remove undesirable impurities that would otherwise decrease the sensitivity of the subsequent photographic analysis. It is the fixing of the gels that can produce a mixed waste depending on the chemicals that are used. Different types of gels and fixing chemicals are used for DNA/RNA sequencing and for protein sequencing. However, the available data do not allow differentiation between these areas.

In the analysis, the fixed gel is exposed to photographic film that is sensitive to the radiation emitted by the radionuclides incorporated in the radioactively labeled peptides or bases. The sequence of peptides or bases in the original DNA, RNA, or protein is determined by an analysis of the exposed film and the repetition of the procedure. In some cases, researchers at NIH have been successful in analyzing gels without first fixing them by using specialized substitute gels that can be analyzed with certain impurities present. This type of procedural modification is dependent upon the particular research application of gel electrophoresis to be successfully implemented.

\subsubsection{High-Performance Liquid Chromatography Scintillation Counting Fluids}

High-performance liquid chromatography (HPLC) scintillation counting fluid wastes are generated when two powerful analytical techniques, HPLC and liquid scintillation counting, are used. HPLC is a type of liquid chromatography in which liquid samples to be analyzed are injected directly into a column through which a solvent is pumped at high speeds and pressures. The various types of molecules contained within the sample are separated as they pass through the column, depending on the specificity of the column, and exit the column at different times, which are characteristic of the different molecular species.

Liquid scintillation counting is a technique to detect beta radiation (also alpha radiation, positrons, and weak X-rays) emitted by radioactively labeled chemicals. In this technique, ionizing radiation passing through a dilute solution of an organic substance causes ionization and excitation of some of the solvent molecules through promotion of pi-orbital electrons to higher energy states. If a suitable solute is present in the solution, these electrons will transfer their excitation energy to the solute molecules, which then emit multiple light flashes (scintillations) through solute fluorescence as they return to lower energy states. The scintillations are then recorded with photomultiplier tubes. In biomedical research, the technique is widely used to measure ${ }^{14} \mathrm{C}$ and ${ }^{3} \mathrm{H}$, as well as other nuclides. When the scintillation counting technique is applied to solvents from an HPLC column, it provides a powerful technique for quantitatively detecting the presence of biochemical species of interest. The key points with respect to waste 
generation are that the use of a suitable solvent with pi-orbital electrons is required together with a solute appropriate for the solvent being used. Many of these solvents are regulated under RCRA as F-listed spent solvents or as characteristic wastes.

\subsubsection{Filter/Blot Washing}

Protein residues that are separated using gel electrophoresis techniques as described in Section 2.1.1 can be transferred from the sequencing gel to a glass fiber filter media substrate coated with a thin layer of noncovalently adsorbed polybase or other media such as sheets of polyvinylidene difluoride. This procedure is referred to as "protein blotting" or "Western blotting" and provides a method of identifying gel-separated proteins with specific binding properties. It provides a replica of the protein separation pattern present in the separation gel. After the protein is transferred to the filter paper, it is washed using a variety of chemicals to remove impurities before further analysis. The filter washings can produce a mixed waste depending on the chemicals used. Again, many of these chemicals are regulated as F-listed spent solvents or as characteristic wastes.

\subsubsection{Cell Culture Labeling}

Many of the research techniques using radioactive labeling of biological molecules require that the radioactive nuclide be biologically incorporated into the structures of cells. This can be done by allowing photosynthesis to occur in an atmosphere containing ${ }^{14} \mathrm{CO}_{2}$, using ${ }^{3} \mathrm{H}$-labeled water in the culturing of cells, or by using ${ }^{32} \mathrm{PO}_{4}$ as a nutrient in a cell culture. The radiologically labeled biological molecules can be recovered from the cell cultures with techniques that require the use of a variety of chemicals. This process can produce a mixed waste if the chemicals are regulated as F-listed spent solvents or as characteristic wastes.

\subsubsection{Protein Precipitation}

Protein solutions are developed and used for a variety of analytical purposes. It is often necessary to ultimately precipitate the proteins from solution as a prelude to separating them from the solution or performing a further step. A common protein-precipitating agent is trichloroacetic acid. The anion of trichloroacetic acid and other acids forms an insoluble salt with proteins when the proteins are in solution in the form of cations. Proteins can also be precipitated from solution by solvents that are miscible in water such as methanol, ethanol, and acetone. Methanol and acetone are regulated as F003 spent solvents. A decomposition product of trichloroacetic acid is chloroform, which is regulated as a toxicity characteristic RCRA waste.

\subsubsection{Autoradiography}

Autoradiography is a technique that allows the resolution and study of structures on the intracellular level. In this procedure, a tissue is cultured and radioactively labeled. Then photographic film is applied to a cut section of the tissue. The portions of the film that are close to radioactive areas in the tissue will darken. When nuclides with suitable characteristics are used, intracellular structures can be resolved to allow the study of cellular structures and functions. Mixed waste can be generated from autoradiography if chemicals, such as methanol, are used to prepare the samples before filming. 


\subsubsection{Radioimmunoassay}

Radioimmunoassays are a technique for detecting the presence and concentration of a variety of biological proteins using a radioactively labeled antigen molecule that binds with specificity to a receptor molecule in a biological system of interest. The technique is used for several hundred different applications such as determining the presence of various hormones, viruses, or other substances. Nuclides commonly used for this procedure are ${ }^{3} \mathrm{H}$ and ${ }^{125} \mathrm{I}$. Mixed wastes are generated with the procedure by the need to separate the antigen from the receptor to complete the test. This is usually done by some type of differential precipitation of proteins or by using other separation techniques such as gel electrophoresis or chromatography. If F-listed solvents, such as methanol, are used in this process, then mixed wastes can be generated.

\subsection{Supplemental Mixed Waste Streams}

The NIH generates two large, and one smaller, supplemental mixed waste streams that are not tracked in the mixed waste database. The first waste stream consists of liquid scintillation fluids contained in vials instead of bulk liquid containers. These vials are used in scintillation counting and then placed in shipping containers for shipment to an offsite incinerator. The total volume of the liquid scintillation fluid vials shipped offsite from 1986 to 1993 (January to June) is shown in Table 2-2.

The second supplemental mixed waste stream was created recently as a result of a research study that began in 1993. This waste stream consists of solid medical pathological waste containing melphalan (a carcinogen) and ${ }^{131} \mathrm{I}$ used as a tracer. This waste is placed in shipping containers for radioactive decay and storage before shipment offsite. The NIH will integrate this waste stream into the mixed waste database tracking system in 1994. Table 2-2 lists the waste volume generated for this waste stream from the study inception through June 1993.

The third mixed waste stream consists of small vials of mercury and other compounds contaminated with ${ }^{3} \mathrm{H}$ that were generated in 1989-1990. These wastes are also listed in Table 2-2. 


\section{DESCRIPTION OF WASTE STREAMS GENERATED BY ONE-TIME OPERATIONS}

A significant number of the mixed waste streams generated at the NIH are from activities that could be described as one-time activities. These waste streams are produced relatively infrequently and are produced by activities that appear to be dissimilar. Table 3-1 contains a summary list of one-time waste streams, the dates they were received by the NIH waste management group, and the waste volume produced. The data suggest that a relatively large proportion of the waste streams are produced as a result of spills and activities of an unplanned nature. Other sources of one-time waste are special projects and activities that produce relatively small amounts of waste and maintenance activities for equipment.

The one-time waste streams are characterized and described further in later portions of the report as the one-time process group. Characterization data for the one-time process group are presented in Sections 4 and 5. 
Table 3-1. Summary of one-time waste generating processes at the NIH.

\begin{tabular}{|c|c|c|}
\hline Date received & $\begin{array}{c}\text { Waste } \\
\text { volume } \\
\text { (L) }\end{array}$ & Waste generation process activity \\
\hline 22 October 1991 & 1 & Abandoned vials \\
\hline 9 June 1992 & 3 & Accidental contamination \\
\hline 31 March 1992 & 18 & Accidental contamination of aqueous waste \\
\hline 17 September 1991 & 20 & Affinity chromatograph binding studies \\
\hline 6 August 1991 & 1 & Aldehyde reduction \\
\hline 6 August 1991 & $<1$ & Aldehyde reduction \\
\hline 2 April 1991 & 20 & Alkaline glucose \\
\hline 2 April 1991 & 20 & Animal destruction \\
\hline 2 April 1991 & 20 & Animal destruction \\
\hline 20 June 1990 & 20 & Animal destruction (prebiopsy) \\
\hline 20 June 1990 & 20 & Animal injection \\
\hline 4 June 1991 & 20 & Animal injection experiment \\
\hline 4 June 1991 & 20 & Animal injection experiment \\
\hline 8 April 1991 & 8 & Animal studies \\
\hline 8 January 1991 & 3 & $\begin{array}{l}\text { Aqueous waste aspirated and unintentionally } \\
\text { contaminated with vacuum pump oil }\end{array}$ \\
\hline 23 October 1990 & 16 & Aspiration dispersion \\
\hline 5 March 1991 & 4 & Aspiration mishap \\
\hline 20 November 1990 & 2 & Broken speed vacuum trap \\
\hline 5 November 1991 & 1 & Broken thermometer contaminated with ${ }^{32} \mathrm{P}$ \\
\hline 17 January 1989 & 4 & Buffer RNA separation \\
\hline 30 July 1991 & $<1$ & Cardiac cell experiments \\
\hline 12 April 1991 & 12 & Cell culture waste \\
\hline 22 January 1993 & 7 & Cell staining \\
\hline 5 December 1990 & 20 & Centrifuge waste \\
\hline 27 November 1990 & 20 & Centrifuge waste \\
\hline 27 November 1990 & 20 & Centrifuge waste \\
\hline 15 January 1991 & 4 & Cesium chloride gradients \\
\hline 19 March 1991 & 20 & Chemical assays \\
\hline 16 June 1992 & $<1$ & Chemical mishap \\
\hline 4 May 1993 & 500 & Chemical reactive \\
\hline 28 January 1992 & 1 & Cholesterol extractions \\
\hline
\end{tabular}


Table 3-1. (continued).

\section{Waste}

volume

Date received

16 July 1991

12 February 1991

9 February 1993

5 June 1991

5 June 1991

5 June 1991

5 June 1991

12 February 1991

12 February 1991

21 July 1992

23 August 1990

15 October 1991

24 March 1992

9 June 1992

8 December 1992

28 January 1992

13 August 1991

30 July 1991

7 May 1991

21 October 1991

31 March 1992

27 March 1990

27 March 1990

4 May 1993

30 March 1993

30 March 1993

30 March 1993

4 April 1993

8 May 1990

16 June 1992

16 June 1992

27 September 1990

20 August 1991
(L)

Waste generation process activity

Chromatography

Chromatography waste

20

10

10

10

10

20

20

20

20

4

4

1

2

4

20

18

8

$<1$

10

20

20

$<1$

$<1$

$<1$

$<1$

18

8

19

19

20

20
Chromium release assays

Clean up of broken bottle

Clean up of broken bottle

Clean up of broken bottle

Clean up of broken tritiated ethyl ether bottle

Cleaning cages

Cleaning cages

Column chromatography solvents

Conjugation of viruses

Contaminated photography chemicals

Contaminated pump oil

Contaminated vacuum pump oil

Copper metabolism in marker

Culture media/unused scintillation fluid

Culture washes and extractions

Cytotoxicity assay

Cytotoxicity assay

Discarding reagent chemicals

Disinfecting labware

Dismantled film developer

Dismantled film developer

Animal death

Animal death

Animal death

Animal death

Enhancer radioactive enhancement

Fluorography

Fluorography

Fluorography

Gamma flow through detector

Glassware cleaning mishap 
Table 3-1. (continued).

\begin{tabular}{|c|c|c|}
\hline Date received & $\begin{array}{c}\text { Waste } \\
\text { volume } \\
\text { (L) }\end{array}$ & Waste generation process activity \\
\hline 15 September 1992 & 18 & Immunoprecipitation \\
\hline 10 March 1992 & 1 & Leftover source vials \\
\hline 12 March 1991 & 1 & Lymphilizer waste \\
\hline 12 March 1991 & 1 & Lymphilizer waste \\
\hline 12 March 1991 & 1 & Lymphilizer waste \\
\hline 17 September 1991 & 1 & Lypholizer waste \\
\hline 22 January 1991 & 20 & Microsphere injection \\
\hline 27 April 1993 & 16 & Miltepoposal \\
\hline 2 April 1991 & 2 & $\begin{array}{l}\text { Mishap with lipholizer (cleaned up and placed in a } \\
\text { flimsy plastic jug) }\end{array}$ \\
\hline 17 February 1993 & 18 & Mistake \\
\hline 20 April 1993 & 1 & Mistake \\
\hline 26 December 1990 & 16 & Molecular extractions/washings \\
\hline 5 September 1990 & 1 & Oil change \\
\hline 25 February 1989 & 2 & Oil change mishap \\
\hline 29 January 1991 & 1 & Oil contaminated in aspiration mishap \\
\hline 23 August 1990 & 4 & Oil replacement \\
\hline 27 April 1993 & 20 & Overshot neutralization washes \\
\hline 12 February 1993 & 20 & Overshot neutralization washes \\
\hline 2 March 1993 & 4 & Overshot $\mathrm{pH}$ \\
\hline 2 March 1993 & 4 & Overshot $\mathrm{pH}$ water wash \\
\hline 19 November 1991 & 2 & Peptide iodination \\
\hline 26 December 1990 & 20 & Peptide synthesis \\
\hline 26 December 1990 & 20 & Peptide synthesis \\
\hline 31 October 1990 & 8 & Peptide synthesis, paper fixing \\
\hline 13 November 1991 & 20 & Plate washes \\
\hline 16 May 1990 & 2 & Protein labeling \\
\hline 29 January 1991 & 8 & Radioactive drugs tests \\
\hline 29 August 1990 & 16 & Radiolabeling ${ }^{35} \mathrm{~S}$ \\
\hline 13 August 1991 & 4 & Rat plasma extractions \\
\hline 23 October 1990 & 20 & Receptor binding assays \\
\hline 19 November 1991 & $<1$ & Resin absorption \\
\hline 1 June 1993 & 35 & Resume breakdown \\
\hline
\end{tabular}


Table 3-1. (continued).

\section{Waste}

volume

Date received

1 February 1991

8 August 1990

26 January 1993

4 June 1991

25 February 1992

7 March 1990

7 January 1992

22 October 1991

25 February 1992

19 February 1991

5 November 1991

7 May 1990

21 July 1987

27 February 1991

30 October 1991

21 May 1991

21 May 1991

7 August 1992

7 August 1992

24 October 1989

27 June 1989
(L)

Waste generation process activity

2 Rinsate from $\mathrm{pH}$ meter probe

16

16

$<1$

18

6

8

1

18

$<1$

19

4

4

20

1

1

1

3

3

4

$<1$

Scintillation counting waste accidently put in aqueous waste container

Solvent extractions

Source vial

Spectrophotometry

Spill cleanup

Spill cleanup

Spill cleanup

Spill cleanup

Spill cleanup

Tagged probe waste

Thin layer chromatography

Unknown container

Unused buffer solution

Uptake assay

Urea buffering

Urea buffering

Used filter

Used filter

Vacuum pump oil change

Vacuum pump oil change 


\section{WASTE STREAM CHARACTERIZATIONS OF THE WASTE GENERATING PROCESSES}

This section presents a chemical and physical characterization of each of the 32 waste generating process groups. These characterizations have been prepared by processing all of the available database information and summarizing the results in compilations that are presented in tabular form. Table 4-1 presents summary information on the chemical properties of $\mathrm{pH}$ and flashpoint of the waste stream processes. The flashpoint was entered in the database using comparative operators in many cases. For comparative analytical purposes, these operators were converted to the first possible true value, and this value was used for numerical comparisons. For example, a value of $>140^{\circ} \mathrm{F}$ would be converted in the numerical analysis to $141^{\circ} \mathrm{F}$ and this value would be reported.

Table 4-2 presents information on chemicals present in the waste streams. For the most part, the database information does not include numerical quantitative chemical composition information. It does contain chemical composition information that generators have provided on tags attached to the waste containers. This information is entered as character data for each record and is inconsistent in format, completeness, and presentation. As a result, comparative numerical data generally cannot be extracted for analytical purposes from this information. However, what can be extracted is the presence or absence of a specific chemical species, which was done. Table 4-2 presents the volumetric percentages of each of the waste streams that contained the chemical species mentioned. For example, HPLC scintillation counting wastes are shown with a value of $55.1 \%$ under methanol. This means that $55.1 \%$ of all of the waste produced by this process was mentioned as containing methanol. Similarly, a value of $60.6 \%$ is shown for this waste under pseudocumene, which means that this percentage of the total waste stream contained pseudocumene.

Information is presented in this way for methanol, acetone, ethanol, phosphoric acid, sodium hydroxide, pseudocumene, acetic acid, trichloroacetic acid, chloroform, acetonitrile, and xylene. These chemicals were selected based on their relatively high frequency of occurrence in the waste stream descriptive data. However, many other chemical species are also present in the waste streams including a wide variety of buffering solutions and a number of proprietary scintillation cocktail fluids such as Flow Scint III, Flow Scint IV, Pico-Aqual, Enhance, and Trucount. Because of the proprietary nature of these fluids, a detailed chemical characterization was not possible.

Table 4-3 presents information on the EPA hazardous waste numbers that were provided for the different waste streams. Multiple waste numbers were used for many waste streams based on the descriptive waste composition data provided by the generators and by testing performed on the waste. Nine waste numbers are presented based on their frequency of occurrence. The percentages shown for each of the waste numbers represent the volume percentage of the waste stream that was designated with the particular EPA waste number. This information therefore shows that a relatively large proportion of the mixed waste received is in the D001, D002, and F003 categories and very little is in the other categories. Some of the wastes do not have an EPA hazardous waste number associated with them. This is particularly true for wastes in the "Cancer Treatment" and "Operating Room" process groups. It is possible that in addition to being 
Table 4-1. Chemical properties of NIH mixed waste.

\begin{tabular}{|c|c|c|c|c|}
\hline Waste generating process & $\begin{array}{c}\text { Waste } \\
\text { volume } \\
\text { (L) }\end{array}$ & $\underset{\text { minimum }}{\mathrm{pH}}$ & $\underset{\text { maximum }}{\mathrm{pH}}$ & $\begin{array}{c}\text { Flashpoint } \\
\text { minimum } \\
\left({ }^{\circ} \mathrm{F}\right)\end{array}$ \\
\hline ATP extractions & 56 & 1.6 & 1.8 & 96 \\
\hline Automated amino assay & 12 & 4.0 & 4.0 & 141 \\
\hline Autoradiography & 852 & 0.2 & 13.0 & 84 \\
\hline Blot washing & 349 & 1.0 & 12.9 & 135 \\
\hline Cancer treatment & 101 & N/A & N/A & N/A \\
\hline Cell assays & 95 & 1.0 & 12.6 & 120 \\
\hline Cell culture labeling & 3,913 & 0.1 & 13.1 & 83 \\
\hline Deprobing membranes & 1,209 & 1.3 & 13.0 & 99 \\
\hline DNA/RNA extractions/sequencing & 1,793 & 0.3 & 12.5 & 75 \\
\hline Electron microscopy & 60.1 & 1.4 & 8.0 & 139 \\
\hline Electrophoresis & 223 & 0.9 & 8.0 & 70 \\
\hline Equipment cleaning & 344 & 0.5 & 14.0 & 90 \\
\hline Filter washes & 8,261 & 0.1 & 14.0 & 65 \\
\hline Gel fixing/washing. & 18,201 & 0.0 & 13.9 & 72 \\
\hline Hormonal labeling & 31 & 1.6 & 6.8 & 92 \\
\hline HPLC scintillation counting & 16,614 & 0.2 & 13.1 & 60 \\
\hline Lipid extraction & 88 & 1.9 & 10.1 & 70 \\
\hline Membrane washing & 42 & 1.0 & 4.1 & 141 \\
\hline One-time processes & 1,652 & 0.6 & 13.1 & 78 \\
\hline Operating room wastes & 156 & N/A & N/A & N/A \\
\hline Perfusion fixation & 453 & 2.7 & 9.6 & 99 \\
\hline Phosphorylation & 50 & 1.0 & 5.7 & 99 \\
\hline Protein harvesting & 34 & 1.1 & 4.1 & 95 \\
\hline Protein precipitation & 1,010 & 0.0 & 10.6 & 78 \\
\hline Radioassay & 1,344 & 0.1 & 12.6 & 63 \\
\hline Radioimmunoassay & 161 & 1.3 & 12.5 & 99 \\
\hline Reverse transcriptase assays & 990 & 0.5 & 5.8 & 99 \\
\hline Silver staining & 508 & 1.2 & 6.7 & 70 \\
\hline Staining/destaining & 292 & 0.1 & 9.4 & 92 \\
\hline Tissue assay & 223 & 0.5 & 9.1 & 84 \\
\hline Tissue staining & 149 & 1.3 & 13.0 & 138 \\
\hline Unknown & 4,342 & 0.3 & 14.0 & 58 \\
\hline
\end{tabular}


Table 4-2. Chemicals typically present in NIH mixed waste.

Volume percent of waste with chemicals present

\begin{tabular}{|c|c|c|c|c|c|c|c|c|c|c|c|c|}
\hline \multirow[b]{2}{*}{ Waste generating process } & \multirow[b]{2}{*}{$\begin{array}{c}\text { Waste } \\
\text { volume } \\
\text { (L) }\end{array}$} & \\
\hline & & Methanol & Acetone & Ethanol & $\begin{array}{l}\text { Phosphoric } \\
\text { acid }\end{array}$ & $\begin{array}{l}\text { Sodium } \\
\text { hydroxide }\end{array}$ & $\begin{array}{l}\text { Pseudo- } \\
\text { cumene }\end{array}$ & $\begin{array}{l}\text { Acetic } \\
\text { acid }\end{array}$ & $\begin{array}{l}\text { Trichloro- } \\
\text { acetic acid }\end{array}$ & Chloroform & Acetonitrile & Xylene \\
\hline ATP extractions & 56 & 100.0 & 100.0 & - & - & - & - & 100.0 & - & - & - & - \\
\hline Automated amino assay & 12 & - & - & - & - & - & - & - & - & - & - & - \\
\hline Autoradiography & 852 & 56.5 & 2.2 & 4.5 & - & 0.2 & 3.3 & 87.0 & 4.5 & 2.3 & - & - \\
\hline Blot washing & 349 & 12.6 & - & - & 27.8 & 22.6 & 2.0 & 11.7 & 5.7 & - & - & - \\
\hline Cancer treatment & 101 & - & - & - & - & - & - & - & - & - & - & - \\
\hline Cell assays & 95 & 22.1 & - & 12.6 & - & 18.9 & 13.7 & 12.6 & 12.6 & - & - & - \\
\hline Cell culture labeling & 3,913 & 46.1 & 6.7 & 22.5 & 5.5 & 3.1 & 5.5 & 30.2 & 28.3 & 24.4 & 0.7 & - \\
\hline Deprobing membranes & 1,209 & 3.0 & - & - & 1.6 & 94.6 & - & - & - & - & 12.9 & - \\
\hline DNA/RNA extractions/sequencing & 1,793 & 53.5 & 0.4 & 18.6 & 1.1 & 2.3 & 12.3 & 49.9 & 7.6 & 12.9 & 0.0 & - \\
\hline Electron microscopy & 601 & - & - & 3.6 & - & - & - & - & - & - & 3.5 & - \\
\hline Electrophoresis & 223 & 54.7 & - & 17.9 & - & 9.0 & - & 61.8 & 9.0 & 9.0 & - & - \\
\hline Equipment cleaning & 344 & 16.3 & 10.8 & 10.5 & - & 6.3 & 2.3 & 2.3 & - & 7.0 & - & - \\
\hline Filter washes & 8,261 & 48.4 & 1.6 & 19.4 & 18.8 & 4.8 & 0.8 & 18.6 & 58.4 & 43.4 & 3.8 & - \\
\hline Gel fixing/washing & 18,201 & 76.7 & 2.4 & 8.9 & 1.7 & 2.1 & 3.7 & 78.4 & 9.8 & 4.2 & 0.0 & - \\
\hline Hormonal labeling & 31 & - & - & 41.2 & - & - & - & 1.6 & - & 58.8 & - & - \\
\hline HPLC scintillation counting & 16,614 & 55.1 & 0.3 & 4.0 & 36.0 & 0.0 & 60.6 & 8.6 & 0.6 & 2.9 & 9.7 & 6.4 \\
\hline Lipid extraction & 88 & 85.2 & 2.3 & 2.3 & - & 20.5 & - & - & - & 94.3 & 3.4 & - \\
\hline Membrane washing & 42 & 41.0 & - & - & - & - & - & 41.0 & 1.2 & - & - & - \\
\hline One-time processes & 1,652 & 13.7 & 2.0 & 9.4 & 1.1 & 9.1 & 3.6 & 9.2 & 8.3 & 9.1 & 2.5 & 0.2 \\
\hline Operating room wastes & 156 & - & - & - & - & - & - & - & - & - & - & - \\
\hline Perfusion fixation & 453 & 19.4 & - & 0.9 & - & 37.1 & - & 5.3 & - & - & - & - \\
\hline Phosphorylation & 50 & 40.0 & - & 16.0 & 56.0 & - & - & - & 36.0 & - & 8.0 & - \\
\hline Protein harvesting & 34 & - & 13.4 & 23.9 & - & - & - & 11.9 & 25.4 & - & - & - \\
\hline Protein precipitation & 1,010 & 14.1 & 4.4 & 12.4 & 2.8 & 2.5 & 1.7 & 6.6 & 49.3 & 14.1 & - & - \\
\hline Radioassay & 1,344 & 17.3 & 3.0 & 11.2 & 10.4 & 2.8 & 0.4 & 7.1 & 18.4 & 29.2 & 2.7 & - \\
\hline
\end{tabular}


Table 4-2. (continued).

Volume percent of waste with chemicals present

\begin{tabular}{|c|c|c|c|c|c|c|c|c|c|c|c|c|}
\hline \multirow[b]{2}{*}{ Waste generating process } & \multirow[b]{2}{*}{$\begin{array}{c}\text { Waste } \\
\text { volume } \\
\text { (L) }\end{array}$} & \\
\hline & & Methanol & Acetone & Ethanol & $\begin{array}{l}\text { Phosphoric } \\
\text { acid }\end{array}$ & $\begin{array}{c}\text { Sodium } \\
\text { hydroxide }\end{array}$ & $\begin{array}{l}\text { Pseudo- } \\
\text { cumene }\end{array}$ & $\begin{array}{l}\text { Acetic } \\
\text { acid }\end{array}$ & $\begin{array}{l}\text { Trichloro- } \\
\text { acetic acid }\end{array}$ & Chloroform & Acetonitrile & Xylene \\
\hline Radioimmunoassay & 161 & 64.6 & - & 60.2 & - & 12.4 & - & 12.4 & - & - & 23.0 & - \\
\hline Reverse transcriptase assays & 990 & 87.9 & - & 2.0 & - & - & - & 20.2 & 96.0 & 87.9 & - & - \\
\hline Silver staining & 508 & 35.6 & - & 28.9 & - & - & - & 14.0 & - & - & 3.9 & - \\
\hline Staining/destaining & 292 & 17.8 & 55.6 & 2.7 & 15.1 & - & - & 19.2 & - & - & - & - \\
\hline Tissue assay & 223 & 11.2 & 3.1 & 15.0 & - & 2.7 & - & 3.1 & 4.5 & 28.0 & 9.4 & - \\
\hline Tissue staining & 149 & 10.8 & - & - & - & - & - & 20.2 & - & - & - & - \\
\hline Unknown & 4,342 & 11.6 & 1.6 & 1.4 & 4.1 & 0.8 & 2.8 & 9.2 & 2.6 & 4.4 & 2.4 & 0.5 \\
\hline
\end{tabular}

Note: A blank indicates the specified waste parameter is not applicable to the indicated waste generating process. 
Table 4-3. Typical EPA hazardous waste numbers for NIH mixed waste.

\begin{tabular}{|c|c|c|c|c|c|c|c|c|c|c|c|}
\hline \multirow[b]{2}{*}{ Waste generating process } & \multirow{2}{*}{$\begin{array}{c}\text { Waste } \\
\text { volume } \\
\text { (L) }\end{array}$} & \multicolumn{10}{|c|}{ Volume percent of waste using EPA hazardous waste number } \\
\hline & & D001 & D002 & D007 & D008 & D009 & D011 & D022 & F001 & $\mathrm{F} 003$ & F005 \\
\hline ATP extractions & 56 & 100 & 100 & - & - & - & - & - & - & 100 & 68 \\
\hline Automated amino assay & 12 & - & - & - & - & - & - & - & - & - & - \\
\hline Autoradiography & 852 & 89 & 38 & - & - & - & - & 2 & - & 63 & 2 \\
\hline Blot washing & 349 & 7 & 28 & - & - & - & - & 11 & - & 13 & - \\
\hline Cancer treatment & 101 & - & - & - & - & - & - & - & - & - & - \\
\hline Cell assays & 95 & 36 & 54 & - & - & - & - & - & - & 15 & - \\
\hline Cell culture labeling & 3,913 & 54 & 31 & 0.4 & - & - & - & 39 & 5.1 & 47 & 12 \\
\hline Deprobing membranes & 1,209 & 16 & 12 & - & - & - & - & - & - & 2 & - \\
\hline DNA/RNA extractions/sequencing & 1,793 & 37 & 16 & - & - & - & - & 13 & 0.5 & 55 & 3 \\
\hline Electron microscopy & 601 & 4 & 7 & - & 67.8 & - & - & - & - & - & - \\
\hline Electrophoresis & 223 & 69 & 38 & - & - & - & - & 9 & - & 59 & - \\
\hline Equipment cleaning & 344 & 32 & 33 & - & - & - & - & 7 & - & 26 & 5 \\
\hline Filter washes & 8,261 & 48 & 58 & - & - & - & - & 60 & - & 48 & 3 \\
\hline Gel fixing/washing & 18,201 & 60 & 23 & - & - & - & 1.1 & 16 & 1.3 & 74 & 1 \\
\hline Hormonal labeling & 31 & 41 & 60 & - & - & - & - & 59 & - & - & - \\
\hline HPLC scintillation counting & 16,614 & 90 & 42 & - & - & - & - & 6 & 0.1 & 62 & 2 \\
\hline Lipid extraction & 88 & 47 & 3 & - & - & $\dot{-}$ & - & 60 & - & 81 & 36 \\
\hline Membrane washing & 42 & - & 1 & - & - & - & - & 1 & - & - & - \\
\hline One-time processes & 1,652 & 26 & 15 & - & 0.4 & 1.2 & - & 10 & 0.1 & 17 & 5 \\
\hline Operating room wastes & 156 & - & - & - & - & - & - & - & - & - & 一 \\
\hline Perfusion fixation & 453 & 17 & - & - & - & - & - & - & - & 19 & - \\
\hline
\end{tabular}


Table 4-3. (continued).

\begin{tabular}{lcccccccccccc}
\hline & \multirow{8}{*}{$\begin{array}{c}\text { Waste } \\
\text { Wolume }\end{array}$} & \multicolumn{8}{c}{ Volume percent of waste using EPA hazardous waste number } \\
\cline { 3 - 11 } \multicolumn{1}{c}{ Waste generating process } & $(\mathrm{L})$ & D001 & D002 & D007 & D008 & D009 & D011 & D022 & F001 & F003 & F005 \\
\hline Phosphorylation & 50 & 48 & 52 & - & - & - & - & 36 & - & 40 & - \\
Protein harvesting & 34 & 27 & 27 & - & - & - & - & - & - & 12 & - \\
Protein precipitation & 1,010 & 21 & 58 & - & - & - & - & 46 & - & 17 & - \\
Radioassay & 1,344 & 26 & 36 & - & - & - & - & 38 & - & 20 & 6 \\
Radioimmunoassay & 161 & 63 & 22 & - & - & - & - & - & - & 65 & 12 \\
Reverse transcriptase assays & 990 & 80 & 58 & - & - & - & - & 88 & - & 86 & - \\
Silver staining & 508 & 70 & 19 & 53.7 & - & - & 51.2 & - & - & 44 & - \\
Staining/destaining & 292 & 12 & 8 & - & - & - & 0.2 & - & - & 11 & - \\
Tissue assay & 223 & 26 & 15 & - & - & 4.5 & - & 27 & - & 13 & - \\
Tissue staining & 149 & 11 & 61 & - & 57.9 & - & - & - & - & 11 & - \\
Unknown & 4,342 & 14 & 21 & - & 0.5 & - & - & 4 & - & 12 & 1.
\end{tabular}

Note: A blank indicates the specified waste parameter is not applicable to the indicated waste generating process. 
low-level radioactive waste, these wastes may be infectious wastes rather than RCRA wastes and may not meet the definition of mixed waste as discussed in Section 1.

Radiological waste properties are presented in Table 4-4. Information is provided for seven radionuclides based on their frequency of use. The percentages shown for each nuclide are the volumetric percentage of the waste stream from a particular process that contained the nuclide. The activity information shown is the volumetric average of the activity information for only that portion of the waste stream which contained the nuclide. These average activities are derived from the radioassay information performed on each waste sample at the NIH. For example, data on the use of tritium with autoradiography indicate that in $44 \%$ of the volume of waste generated, tritium was used with an average activity concentration of $0.009 \mathrm{mCi} / \mathrm{L}$. As this information shows, ${ }^{3} \mathrm{H}$ is the most commonly used nuclide and ${ }^{35} \mathrm{~S}$ is the next most common. The characterization information presented here provides insight into the types of waste being generated from biomedical research activities such as those occurring at the NIH.

Table 4-5 presents radiological properties for the two supplemental mixed waste streams described in Section 2.2. Information is provided for the seven radionuclides presented for the mixed wastes described in Table 4-4. The liquid scintillation vials also contain other radionuclides at generally lower activity levels including ${ }^{22} \mathrm{Na},{ }^{36} \mathrm{Cl},{ }^{51} \mathrm{Cr},{ }^{46} \mathrm{Sc},{ }^{45} \mathrm{Ca}$, and ${ }^{86} \mathrm{Rb}$. 
Table 4-4. Radiological properties of $\mathrm{NIH}$ mixed waste.

\begin{tabular}{|c|c|c|c|c|c|c|c|c|c|c|c|c|c|c|c|}
\hline \multirow[b]{2}{*}{ Waste generating process } & \multirow[b]{2}{*}{$\begin{array}{c}\text { Waste } \\
\text { volume } \\
\text { (L) }\end{array}$} & \multicolumn{2}{|c|}{$3_{\mathrm{H}}$} & \multicolumn{2}{|c|}{${ }^{14} \mathrm{C}$} & \multicolumn{2}{|c|}{$32 \mathrm{p}$} & \multicolumn{2}{|c|}{${ }^{35} \mathrm{~S}$} & \multicolumn{2}{|c|}{$125_{1}$} & \multicolumn{2}{|c|}{$131_{I}$} & \multicolumn{2}{|c|}{${ }^{238} \mathrm{U}$} \\
\hline & & $\begin{array}{c}\% \text { of } \\
\text { volume }\end{array}$ & $\begin{array}{l}\text { Average } \\
\text { activity } \\
\text { (mCi/L) }\end{array}$ & $\begin{array}{c}\% \text { of } \\
\text { volume }\end{array}$ & $\begin{array}{l}\text { Average } \\
\text { activity } \\
\text { (mCi/L) }\end{array}$ & $\begin{array}{c}\% \text { of } \\
\text { volume }\end{array}$ & $\begin{array}{l}\text { Average } \\
\text { activity } \\
\text { (mCi/L) }\end{array}$ & $\begin{array}{c}\% \text { of } \\
\text { volume }\end{array}$ & $\begin{array}{l}\text { Average } \\
\text { activity } \\
\text { (mCi/L) }\end{array}$ & $\begin{array}{c}\% \text { of } \\
\text { volume }\end{array}$ & $\begin{array}{l}\text { Average } \\
\text { activity } \\
\text { (mCi/L) }\end{array}$ & $\begin{array}{c}\% \text { of } \\
\text { volume }\end{array}$ & $\begin{array}{l}\text { Average } \\
\text { activity } \\
\text { (mCi/L) }\end{array}$ & $\begin{array}{c}\% \text { of } \\
\text { volume }\end{array}$ & $\begin{array}{l}\text { Average } \\
\text { activity } \\
\text { (mCi/L) }\end{array}$ \\
\hline ATP extractions & 56 & - & - & - & - & 100.0 & 0.012 & - & - & - & - & - & - & - & - \\
\hline Automated amino assay & 12 & - & - & - & - & - & - & - & - & 100.0 & 0.001 & - & - & - & - \\
\hline Autoradiography & 852 & 44.0 & 0.009 & 5.4 & 0.000 & 30.6 & 0.000 & 75.2 & 0.020 & 2.1 & - & - & - & - & - \\
\hline Blot washing & 349 & 22.9 & 0.015 & - & - & 75.4 & 0.004 & 28.4 & 0.004 & 2.0 & 0.004 & - & - & - & - \\
\hline Cancer treatment & 101 & - & - & - & - & - & - & - & - & - & - & 100.0 & 0.085 & - & - \\
\hline Cell assays & 95 & 33.1 & 0.053 & 1.1 & 0.000 & 31.5 & 0.012 & 45.8 & 0.183 & - & - & - & - & - & - \\
\hline Cell culture labelling & 3,913 & 77.0 & 0.081 & 14.0 & 0.011 & 9.6 & 0.019 & 29.7 & 0.030 & 4.3 & 0.015 & - & - & - & - \\
\hline Deprobing membranes & 1,209 & 29.9 & 0.022 & - & - & 70.1 & 0.009 & 3.7 & 0.000 & 0.3 & 0.015 & - & - & - & - \\
\hline DNA/RNA extractions/sequencing & 1,793 & 30.4 & 0.054 & 2.7 & 0.009 & 23.6 & 0.008 & 64.7 & 0.015 & 0.2 & 0.015 & - & - & - & - \\
\hline Electron microscopy & 601 & 28.6 & 0.027 & 2.8 & 0.001 & - & - & 3.3 & 0.001 & - & - & - & - & 89.8 & 0.008 \\
\hline Electrophoresis & 223 & 27.0 & 0.018 & 9.0 & 0.001 & 49.3 & 0.020 & 40.8 & 0.048 & 8.1 & 0.001 & - & - & - & - \\
\hline Equipment cleaning & 344 & 69.0 & 0.177 & 11.9 & 0.006 & 17.9 & 0.052 & 7.0 & 0.156 & - & - & - & - & - & - \\
\hline Filter washes & 8,261 & 55.3 & 0.073 & 6.6 & 0.021 & 34.1 & 0.012 & 32.6 & 0.022 & 1.5 & 0.016 & - & - & - & - \\
\hline Gel fixing/washing & 18,201 & 26.5 & 0.060 & 4.5 & 0.002 & 21.1 & 0.010 & 69.1 & 0.025 & 3.7 & 0.004 & - & - & - & - \\
\hline Hormonal labeling & 31 & 39.2 & 0.000 & 58.8 & 0.000 & - & - & - & - & - & - & - & - & - & - \\
\hline HPLC scintillation counting & 16,614 & 86.5 & 0.023 & 12.8 & 0.004 & 3.0 & 0.012 & 9.4 & 0.047 & 1.7 & 0.007 & - & - & - & - \\
\hline Lipid extraction & 88 & 97.7 & 0.829 & 20.5 & 0.151 & 8.0 & 0.003 & - & - & - & - & - & - & - & - \\
\hline Membrane washing & 42 & 41.0 & 0.104 & - & - & 25.3 & 0.001 & - & - & 33.7. & 0.003 & - & - & - & - \\
\hline One-time processes & 1,652 & 32.7 & 0.080 & 6.8 & 0.282 & 8.9 & 0.032 & 20.0 & 0.078 & 4.3 & 0.015 & - & - & - & - \\
\hline Operating room wastes & 156 & - & - & - & - & - & - & - & - & - & - & 100.0 & 0.086 & - & - \\
\hline Perfusion fixation & 453 & 41.1 & 0.005 & - & - & 0.9 & - & 0.9 & - & 7.7 & 0.002 & - & - & - & - \\
\hline Phosphorylation & 50 & 8.0 & 0.000 & - & - & 52.0 & 0.006 & $40: 0$ & 0.000 & - & - & - & - & - & - \\
\hline Protein harvesting & 34 & 86.6 & 0.011 & - & - & - & - & 1.5 & 2.120 & 11.9 & 0.000 & - & - & - & - \\
\hline Protein precipitation & 1,010 & 52.2 & 0.282 & 5.7 & 0.004 & 21.9 & 0.179 & 22.5 & 0.041 & 8.6 & 0.018 & - & - & - & - \\
\hline Radioassay & 1,344 & 71.3 & 0.174 & 22.2 & 0.022 & 8.7 & 0.014 & 44.5 & 0.019 & 2.4 & 0.054 & - & - & - & - \\
\hline Radioimmunoassay & 161 & 47.2 & 0.246 & - & - & 12.4 & 0.003 & 34.8 & 0.154 & 62.7 & 0.004 & - & - & - & - \\
\hline Reverse transcriptase assays & 990 & 100.0 & 0.130 & - & - & - & - & 20.2 & - & - & - & - & - & - & - \\
\hline
\end{tabular}


Table 4-4. (continued).

\begin{tabular}{|c|c|c|c|c|c|c|c|c|c|c|c|c|c|c|c|}
\hline \multirow[b]{2}{*}{ Waste generating process } & \multirow[b]{2}{*}{$\begin{array}{c}\text { Waste } \\
\text { volume } \\
\text { (L) }\end{array}$} & \multicolumn{2}{|c|}{$3_{\mathrm{H}}$} & \multicolumn{2}{|c|}{${ }^{14} \mathrm{C}$} & \multicolumn{2}{|c|}{${ }^{32} \mathrm{P}$} & \multicolumn{2}{|c|}{${ }^{35} \mathrm{~S}$} & \multicolumn{2}{|c|}{$125_{I}$} & \multicolumn{2}{|c|}{${ }^{131} 1_{I}$} & \multicolumn{2}{|c|}{${ }^{238} \mathrm{U}$} \\
\hline & & $\begin{array}{c}\% \text { of } \\
\text { volume }\end{array}$ & $\begin{array}{l}\text { Average } \\
\text { activity } \\
\text { (mCi/L) }\end{array}$ & $\begin{array}{c}\text { \% of } \\
\text { volume }\end{array}$ & $\begin{array}{l}\text { Average } \\
\text { activity } \\
\text { (mCi/L) }\end{array}$ & $\begin{array}{c}\% \text { of } \\
\text { volume }\end{array}$ & $\begin{array}{l}\text { Average } \\
\text { activity } \\
\text { (mCi/L) }\end{array}$ & $\begin{array}{c}\text { \% of } \\
\text { volume }\end{array}$ & $\begin{array}{l}\text { Average } \\
\text { activity } \\
\text { (mCi } / 2 \text { ) }\end{array}$ & $\begin{array}{c}\% \text { of } \\
\text { volume }\end{array}$ & $\begin{array}{l}\text { Average } \\
\text { activity } \\
\text { (mCi/L) }\end{array}$ & $\begin{array}{c}\% \text { of } \\
\text { volume }\end{array}$ & $\begin{array}{l}\text { Average } \\
\text { activity } \\
\text { (mCi/L) }\end{array}$ & $\begin{array}{c}\% \text { of } \\
\text { volume }\end{array}$ & $\begin{array}{l}\text { Average } \\
\text { activity } \\
\text { (mCi/L) }\end{array}$ \\
\hline Silver staining & 508 & 40.9 & 0.001 & - & - & 59.8 & 0.005 & 11.4 & 0.013 & - & - & - & - & - & - \\
\hline Staining/destaining & 292 & 8.2 & 0.260 & - & - & 36.4 & 0.025 & 29.3 & 0.157 & 6.9 & 0.065 & - & - & - & - \\
\hline Tissue assay & 223 & 52.6 & 0.073 & 10.8 & 0.022 & - & - & 22.5 & 0.016 & 16.1 & 0.003 & - & - & - & - \\
\hline Tissue staining & 149 & 1.0 & 0.003 & 9.4 & 0.020 & 12.8 & 0.008 & 23.6 & 0.020 & - & - & - & - & 57.9 & 0.001 \\
\hline Unknown & 4,342 & 53.3 & 0.048 & 17.7 & 0.020 & 20.1 & 0.039 & 26.5 & 0.048 & 3.7 & 0.006 & - & - & 1.1 & 0.001 \\
\hline
\end{tabular}

Note: A blank indicates the specified waste parameter is not applicable to the indicated waste generating process. 
Table 4-5. Radiological properties of supplemental NIH mixed waste.

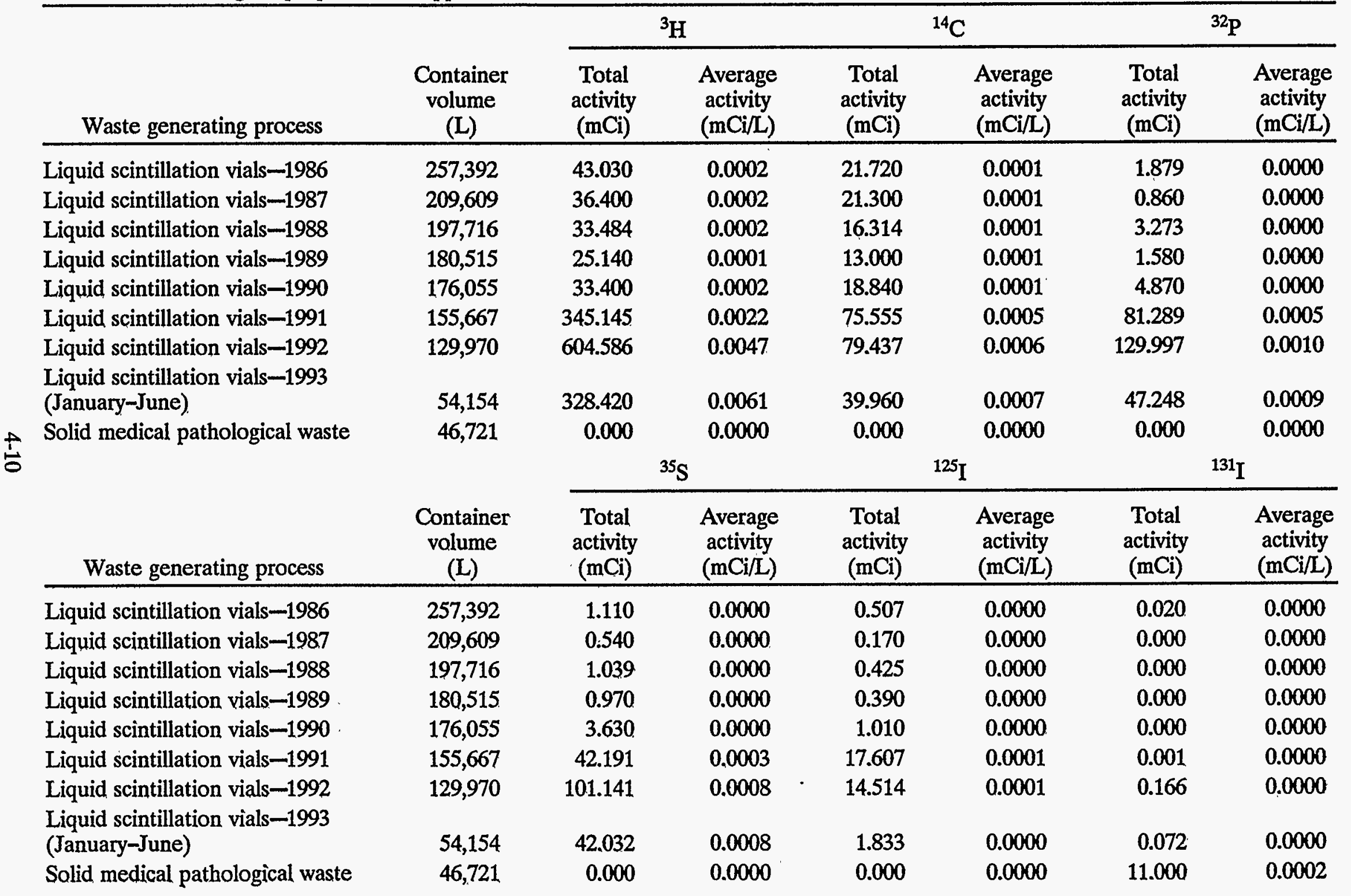




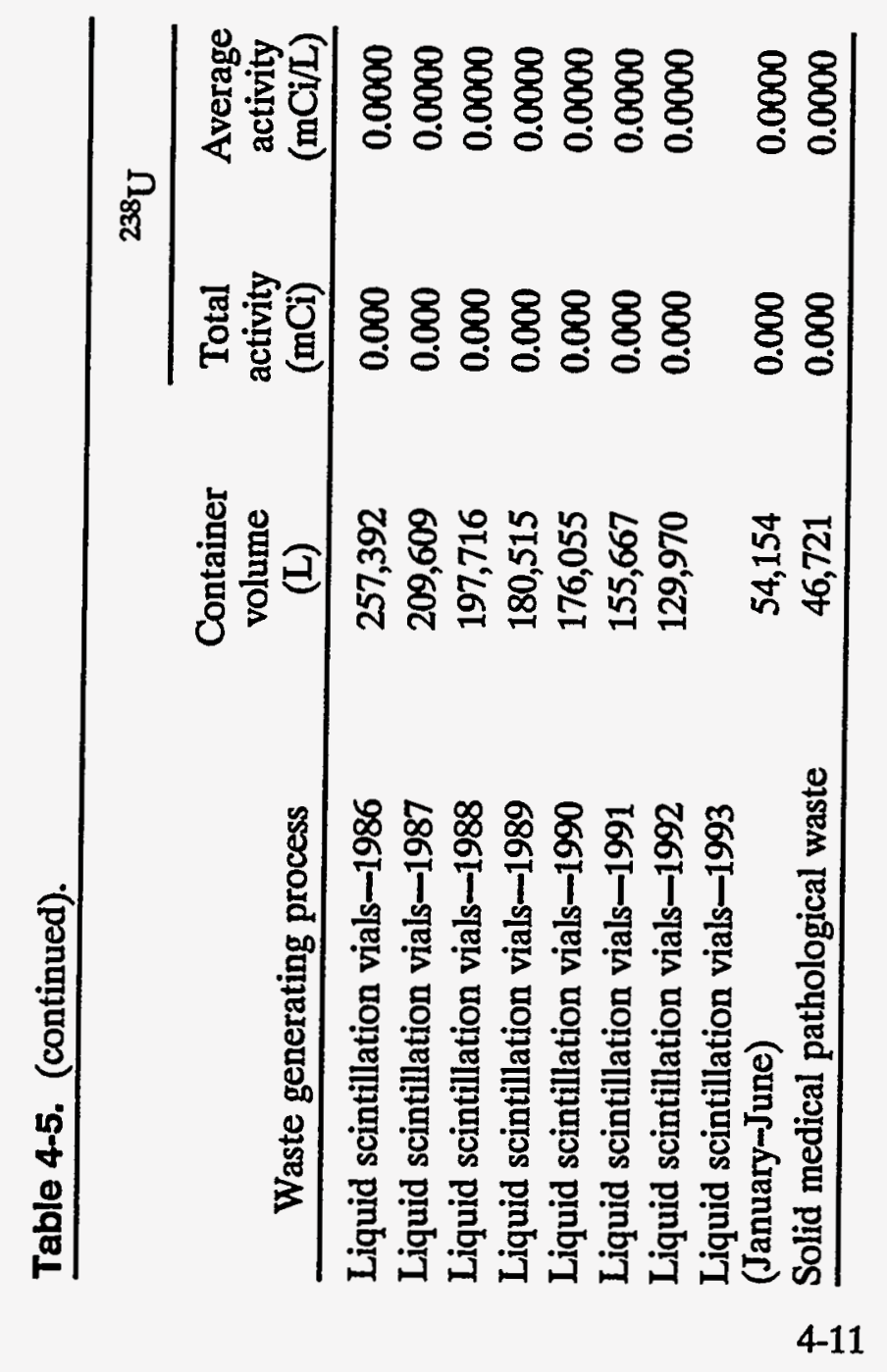




\section{IDENTIFICATION AND CATEGORIZATION OF WASTE STREAMS WITH LIMITED TREATMENT/DISPOSAL OPTIONS}

The NIH waste management facility includes an extensive waste processing capability. A carbon adsorption system has been successfully tested and placed into operation for removing trace chloroform and phenol contaminants from aqueous waste streams. Tanks and equipment are available for neutralizing acidic and alkaline waste streams. Other tanks can be used for holding waste to allow radioactive decay of nuclides with short half-lives to take place before sewer discharge. Onsite incineration capability exists for a few of the wastes, including facilities to place small volumes of other wastes in bulk containers and transport them to offsite waste treatment and disposal facilities. NIH is currently reevaluating the continuation of onsite medical waste incineration, including radioactive medical waste, and this option may not be available in the future.

The NIH evaluates mixed waste as it is received at the waste processing facility. Based on this evaluation, a determination is made as to whether disposal options exist for the waste, and recommended NIH treatment codes are assigned to the waste. An NIH treatment code of 02 indicates that no treatment or disposal options are available for the waste. The waste is packaged and labeled for indefinite long-term onsite storage until treatment or disposal facilities become available. The NIH determined that approximately one-third of the waste received during the 1989 to 1993 study period cannot be disposed of using currently available disposal options for mixed waste. Because no disposal options are available, this waste has been placed into bulk containers and is currently being stored at the NIH. Tables 5-1 through 5-4 present chemical properties, chemicals present, EPA hazardous waste numbers, and radiological properties for this waste. Generally, the radiological activity levels of this waste are higher than the comparable activity levels of the overall waste stream characterized in Section 4. Since the no disposal option waste is a subset of the overall waste stream, this indicates that the waste streams with the highest activities are being diverted to storage at $\mathrm{NIH}$.

Some of the waste shown as having no disposal options in the database records is produced by waste generating processes that have typically not produced such wastes. An example of this would be HPLC scintillation counting wastes. Even though disposal options exist for HPLC scintillation counting wastes, a small volume of these wastes (approximately $4 \%$ ) are described in the database and shown in Tables 5-1 through 5-4 as having no disposal options. It appears likely that a small amount of the HPLC scintillation counting wastes were combined with wastes from other processes to produce a combined waste that does not presently have a disposal option.

Another significant proportion of the overall waste stream contains wastes that are believed to have treatment and disposal options but that have not been disposed of and are currently being stored. These wastes are referred to as "waste in process" in this report and are described in detail in Tables 5-5 through 5-8. This waste has not been disposed of due to treatment capacity limitations, transportation limitations, processing and handling limitations, or the recent arrival of the waste at the NIH waste processing area. 
Table 5-1. Chemical properties of NIH mixed waste with no disposal options.

\begin{tabular}{|c|c|c|c|c|}
\hline Waste generating process & $\begin{array}{c}\text { Waste } \\
\text { volume } \\
\text { (L) }\end{array}$ & $\underset{\text { minimum }}{\mathrm{pH}}$ & $\underset{\text { maximum }}{\mathrm{pH}}$ & $\begin{array}{c}\text { Flashpoint } \\
\text { minimum } \\
\left({ }^{\circ} \mathrm{F}\right)\end{array}$ \\
\hline ATP extractions & 0 & N/A & N/A & N/A \\
\hline Automated amino assay & 0 & N/A & N/A & N/A \\
\hline Autoradiography & 513 & 1.0 & 13.0 & 94 \\
\hline Blot washing & 89 & 1.0 & 11.3 & 135 \\
\hline Cancer treatment & 0 & N/A & N/A & N/A \\
\hline Cell assays & 35 & 1.0 & 4.4 & 120 \\
\hline Cell culture labeling & 1,842 & 0.3 & 13.1 & 88 \\
\hline Deprobing membranes & 154 & 9.4 & 12.9 & 99 \\
\hline DNA/RNA extractions/sequencing & 729 & 0.3 & 12.5 & 78 \\
\hline Electron microscopy & 29 & 5.4 & 7.5 & 139 \\
\hline Electrophoresis & 101 & 1.9 & 6.7 & 80 \\
\hline Equipment cleaning & 97 & 3.1 & 14.0 & 99 \\
\hline Filter washes & 3,798 & 0.1 & 12.8 & 82 \\
\hline Gel fixing/washing & 9,721 & 0.0 & 13.4 & 72 \\
\hline Hormonal labeling & 30 & 1.6 & 6.8 & 92 \\
\hline HPLC scintillation counting & 616 & 0.9 & 8.2 & 70 \\
\hline Lipid extraction & 72 & 1.9 & 10.1 & 70 \\
\hline Membrane washing & 17 & 3.1 & 3.1 & 141 \\
\hline One-time processes & 512 & 0.6 & 12.5 & 78 \\
\hline Operating room wastes & 0 & $\mathrm{~N} / \mathrm{A}$ & N/A & N/A \\
\hline Perfusion fixation & 110 & 2.7 & 9.6 & 99 \\
\hline Phosphorylation & 24 & 3.8 & 5.7 & 99 \\
\hline Protein harvesting & 5 & 1.8 & 3.7 & 141 \\
\hline Protein precipitation & 455 & 0.0 & 6.0 & 78 \\
\hline Radioassay & 562 & 0.2 & 12.6 . & 96 \\
\hline Radioimmunoassay & 124 & 1.3 & 7.7 & 99 \\
\hline Reverse transcriptase assays & 670 & 0.8 & 5.8 & 99 \\
\hline Silver staining & 306 & 1.2 & 6.7 & 70 \\
\hline Staining/destaìning & 45 & $2: 0$ & 9.4 & 139 \\
\hline Tissue assay & 103 & 0.5 & 9.1 & 84 \\
\hline Tissue staining & 35 & 1.3 & 11.6 & 139 \\
\hline Unknown & 735 & 0.3 & 14.0 & 60 \\
\hline
\end{tabular}


Table 5-2. Chemicals typically present in NIH mixed waste with no disposal options.

Volume percent of waste with chemicals present

\begin{tabular}{|c|c|c|c|c|c|c|c|c|c|c|c|c|}
\hline \multirow[b]{2}{*}{ Waste generating process } & \multirow[b]{2}{*}{$\begin{array}{c}\text { Waste } \\
\text { volume } \\
\text { (L) }\end{array}$} & \multicolumn{11}{|c|}{ Volume percent of waste with chemicals present } \\
\hline & & Methanol & Acetone & Ethanol & $\begin{array}{c}\text { Phosphoric } \\
\text { acid }\end{array}$ & $\begin{array}{c}\text { Sodium } \\
\text { hydroxide }\end{array}$ & $\begin{array}{l}\text { Pseudo- } \\
\text { cumene }\end{array}$ & $\begin{array}{c}\text { Acetic } \\
\text { acid }\end{array}$ & $\begin{array}{l}\text { Trichloro- } \\
\text { acetic acid }\end{array}$ & Chloroform & Acetonitrile & Xylene \\
\hline ATP extractions & - & - & - & - & - & - & - & - & - & - & - & - \\
\hline Automated amino assay & - & - & - & - & - & - & - & - & - & - & - & - \\
\hline Autoradiography & 513 & 47.4 & 3.7 & 7.4 & - & 0.4 & 1.6 & 93.6 & 3.5 & - & - & - \\
\hline Blot washing & 89 & 49.4 & - & - & 22.5 & 7.9 & 7.9 & 27.0 & 22.5 & - & - & - \\
\hline Cancer treatment & - & - & - & - & - & - & - & - & - & - & - & - \\
\hline Cell assays & 35 & 59.8 & - & 34.2 & - & - & 37.0 & 34.2 & 34.2 & - & - & - \\
\hline Cell culture labeling & 1,842 & 57.0 & 2.9 & 28.8 & 5.2 & 2.6 & 1.4 & 19.4 & 44.0 & 39.8 & 1.6 & - \\
\hline Deprobing membranes & 154 & 10.4 & - & - & - & 88.3 & - & - & - & - & 89.6 & - \\
\hline DNA/RNA/extractions/sequencing & 729 & 63.8 & 1.1 & 13.0 & - & 3.3 & 2.7 & 52.8 & 10.4 & 25.2 & 0.0 & - \\
\hline Electron microscopy & 29 & - & - & - & - & - & - & - & - & - & 28.4 & - \\
\hline Electrophoresis & 101 & 45.5 & - & 19.8 & - & - & - & 63.4 & - & 19.8 & - & - \\
\hline Equipment cleaning & 97 & 24.7 & 34.0 & 37.1 & - & - & 8.2 & - & - & 16.5 & - & - \\
\hline Filter washes & 3,798 & 60.0 & 1.4 & 19.2 & 1.7 & 1.8 & 1.8 & 10.1 & 89.0 & 75.9 & 1.5 & - \\
\hline Gel fixing/washing & 9,721 & 93.1 & 1.2 & 3.6 & 1.1 & 2.2 & 0.5 & 86.2 & 5.4 & 6.4 & 0.1 & - \\
\hline Hormonal labeling & 30 & - & - & 40.0 & - & - & - & - & - & 60.0 & - & - \\
\hline HPLC scintillation counting & 616 & 50.1 & - & 5.5 & 27.7 & - & 41.1 & 6.7 & 1.3 & 7.1 & 16.2 & 8.3 \\
\hline Lipid extraction & 72 & 81.9 & 2.8 & 2.8 & - & 25.0 & - & - & - & 93.1 & 4.2 & - \\
\hline Membrane washing & 17 & 100.0 & - & - & - & - & - & 100.0 & - & - & - & - \\
\hline One-time processes & 512 & 44.0 & 3.3 & 26.7 & - & 12.3 & 8.2 & 15.8 & 26.8 & 29.3 & 8.2 & 0.8 \\
\hline Operating room wastes & - & - & - & - & - & - & - & - & - & - & - & - \\
\hline Perfusion fixation & 110 & 80.0 & - & 3.6 & - & 16.4 & - & 3.6 & - & - & - & - \\
\hline Phosphorylation & 24 & 83.3 & - & - & 83.3 & - & - & - & - & - & 16.7 & - \\
\hline Protein harvesting & 5 & - & 100.0 & - & - & - & - & 88.9 & 11.1 & - & - & - \\
\hline Protein precipitation & 455 & 31.2 & 8.8 & 23.5 & - & - & 3.7 & 14.7 & 74.5 & 24.2 & - & - \\
\hline Radioassay & 562 & 39.6 & 5.0 & 18.7 & 3.6 & 4.4 & 0.9 & 7.2 & 36.8 & 66.7 & 6.4 & - \\
\hline Radioimmunoassay & 124 & 83.9 & - & 64.5 & - & - & - & - & - & - & 16.1 & - \\
\hline
\end{tabular}


Table 5-2. (continued).

\begin{tabular}{|c|c|c|c|c|c|c|c|c|c|c|c|c|}
\hline \multirow[b]{2}{*}{ Waste generating process } & \multirow[b]{2}{*}{$\begin{array}{c}\text { Waste } \\
\text { volume } \\
\text { (L) }\end{array}$} & \multicolumn{11}{|c|}{ Volume percent of waste with chemicals present } \\
\hline & & Methanol & Acetone & Ethanol & $\begin{array}{l}\text { Phosphoric } \\
\text { acid }\end{array}$ & $\begin{array}{c}\text { Sodium } \\
\text { hydroxide }\end{array}$ & $\begin{array}{l}\text { Pseudo- } \\
\text { cumene }\end{array}$ & $\begin{array}{l}\text { Acetic } \\
\text { acid }\end{array}$ & $\begin{array}{l}\text { Trichloro- } \\
\text { acetic acid }\end{array}$ & Chloroform & Acetonitrile & Xylene \\
\hline Reverse transcriptase assays & 670 & 97.0 & - & 3.0 & - & - & - & - & 100.0 & 100.0 & - & - \\
\hline Silver staining & 306 & 42.5 & - & 37.9 & - & - & - & 13.1 & - & - & 6.5 & - \\
\hline Staining/destaining & 45 & 98.9 & - & 18.0 & 36.0 & - & - & 98.9 & - & - & - & - \\
\hline Tissue assay & 103 & 20.3 & 6.8 & 24.7 & - & - & - & 6.8 & 9.7 & 60.5 & 20.3 & - \\
\hline Tissue staining & 35 & 45.7 & - & - & - & - & - & 45.7 & - & - & - & - \\
\hline Unknown & 735 & 29.0 & 6.6 & 6.8 & 5.4 & 0.8 & 5.8 & 15.5 & 4.7 & 22.1 & 8.7 & 2.7 \\
\hline
\end{tabular}


Table 5-3. Typical EPA hazardous waste numbers for NIH mixed waste with no disposal options.

\begin{tabular}{|c|c|c|c|c|c|c|c|c|c|c|c|}
\hline \multirow[b]{2}{*}{ Waste generating process } & \multirow{2}{*}{$\begin{array}{c}\text { Waste } \\
\text { volume } \\
(\mathrm{L})\end{array}$} & \multicolumn{10}{|c|}{ Volume percent of waste using EPA hazardous waste number } \\
\hline & & D001 & $\mathrm{D} 002$ & D007 & D008 & D009 & D011 & D022 & F001 & $\mathrm{F} 003$ & F005 \\
\hline ATP extractions & - & - & - & - & - & - & - & - & - & - & - \\
\hline Automated amino assay & - & - & - & - & - & - & - & - & - & - & - \\
\hline Autoradiography & 513 & 90 & 52 & - & - & - & - & - & - & 55 & 3 \\
\hline Blot washing & 89 & 27 & 45 & - & - & - & - & 45 & - & 49 & - \\
\hline Cancer treatment & - & - & - & - & - & - & - & - & - & 一 & - \\
\hline Cell assays & 35 & 99 & 4 & - & - & - & - & - & - & 40 & - \\
\hline Cell culture labeling & 1,842 & 68 & 54 & 0.9 & - & - & - & 48 & 0.0 & 59 & 2 \\
\hline Deprobing membranes & 154 & 100 & 6 & - & - & - & - & - & - & - & - \\
\hline DNA/RNA extractions/sequencing & 729 & 53 & 19 & - & - & - & - & 26 & 1.2 & 66 & 6 \\
\hline Electron microscopy & 29 & 28 & - & - & 27.9 & - & - & - & - & - & - \\
\hline Electrophoresis & 101 & 71 & 28 & - & - & - & - & 20 & - & 47 & - \\
\hline Equipment cleaning & 97 & 79 & 21 & - & - & - & - & 16 & - & 59 & 16 \\
\hline Filter washes & 3,798 & 63 & 80 & - & - & - & - & 87 & - & 60 & 0.4 \\
\hline Gel fixing/washing & 9,721 & 68 & 29 & - & - & - & - & 8 & 0.2 & 89 & 0.2 \\
\hline Hormonal labeling & 30 & 40 & 60 & - & - & - & - & 60 & - & - & - \\
\hline HPLC scintillation counting & 616 & 78 & 55 & - & - & - & - & 6 & - & 58 & - \\
\hline Lipid extraction & 72 & 54 & 4 & - & - & - & - & 71 & - & 96 & 44 \\
\hline Membrane washing & 17 & - & - & - & - & - & - & - & - & - & - \\
\hline One-time processes & 512 & 76 & 40 & - & - & 3.9 & - & 33 & 0.2 & 54 & 12 \\
\hline Operating room wastes & - & - & - & - & - & - & - & - & - & - & - \\
\hline Perfusion fixation & 110 & 51 & - & - & - & - & - & - & - & 80 & - \\
\hline Phosphorylation & 24 & 100 & - & - & - & - & - & - & - & 83 & - \\
\hline
\end{tabular}


Table 5-3. (continued).

\begin{tabular}{|c|c|c|c|c|c|c|c|c|c|c|c|}
\hline \multirow[b]{2}{*}{ Waste generating process } & \multirow{2}{*}{$\begin{array}{l}\text { Waste } \\
\text { volume } \\
\text { (L) }\end{array}$} & \multicolumn{10}{|c|}{ Volume percent of waste using EPA hazardous waste number } \\
\hline & & $\mathrm{D} 001$ & $\mathrm{D} 002$ & $\mathrm{D} 007$ & D008 & D009 & D011 & $\mathrm{D} 022$ & F001 & F003 & F005 \\
\hline Protein harvesting & 5 & - & - & - & - & - & - & - & - & 89 & - \\
\hline Protein precipitation & 455 & 46 & 82 & - & - & - & - & 87 & - & 33 & - \\
\hline Radioassay & 562 & 49 & 66 & - & - & - & - & 81 & - & 45 & 11 \\
\hline Radioimmunoassay & 124 & 68 & 13 & - & - & - & 一 & - & - & 84 & 16 \\
\hline Reverse transcriptase assays & 670 & 88 & 76 & - & - & - & - & 100 & - & 94 & - \\
\hline Silver staining & 306 & 69 & 13 & $\$ 2.3$ & - & - & 54.2 & - & - & 49 & - \\
\hline Staining/destaining & 45 & 54 & 36 & - & - & - & 1.1 & - & - & 54 & - \\
\hline Tissue assay & 103 & 56 & 14 & - & - & 9.7 & - & 58 & - & 27 & - \\
\hline Tissue staining & 35 & 46 & 46 & - & - & - & - & - & - & 46 & - \\
\hline Unknown & 735 & 36 & 23 & - & 2.7 & - & - & 18 & - & 25 & 1 \\
\hline
\end{tabular}

Note: A blank indicates the specified waste parameter is not applicable to the indicated waste generating process. 
Table 5-4. Radiological properties of $\mathrm{NIH}$ mixed waste with no disposal options.

\begin{tabular}{|c|c|c|c|c|c|c|c|c|c|c|c|c|c|c|c|}
\hline \multirow[b]{2}{*}{ Waste generating process } & \multirow[b]{2}{*}{$\begin{array}{c}\text { Waste } \\
\text { volume } \\
\text { (L) }\end{array}$} & \multicolumn{2}{|c|}{$3_{H}$} & \multicolumn{2}{|c|}{${ }^{14} \mathrm{C}$} & \multicolumn{2}{|c|}{${ }^{32} \mathrm{P}$} & \multicolumn{2}{|c|}{${ }^{35} \mathrm{~s}$} & \multicolumn{2}{|c|}{${ }^{125_{I}}$} & \multicolumn{2}{|c|}{${ }^{131_{I}}$} & \multicolumn{2}{|c|}{${ }^{238} \mathbf{U}$} \\
\hline & & $\begin{array}{c}\% \text { of } \\
\text { volume }\end{array}$ & $\begin{array}{l}\text { Average } \\
\text { activity } \\
\text { (mCi/L) }\end{array}$ & $\begin{array}{c}\% \text { of } \\
\text { volume }\end{array}$ & $\begin{array}{l}\text { Average } \\
\text { activity } \\
(\mathrm{mCi} / \mathrm{L})\end{array}$ & $\begin{array}{c}\% \text { of } \\
\text { volume }\end{array}$ & $\begin{array}{c}\text { Average } \\
\text { activity } \\
\text { (mCi/L) }\end{array}$ & $\begin{array}{c}\% \text { of } \\
\text { volume }\end{array}$ & $\begin{array}{c}\text { Average } \\
\text { activity } \\
\text { (mCi/L) }\end{array}$ & $\begin{array}{c}\% \text { of } \\
\text { volume }\end{array}$ & $\begin{array}{l}\text { Average } \\
\text { activity } \\
\text { (mCi/L) }\end{array}$ & $\begin{array}{l}\% \text { of } \\
\text { volume }\end{array}$ & $\begin{array}{l}\text { Average } \\
\text { activity } \\
\text { (mCi/L) }\end{array}$ & $\begin{array}{c}\% \text { of } \\
\text { volume }\end{array}$ & $\begin{array}{l}\text { Average } \\
\text { activity } \\
\text { (mCi/L) }\end{array}$ \\
\hline ATP extractions & - & - & - & - & - & - & - & - & - & - & - & - & - & - & - \\
\hline Automated amino assay & - & - & - & - & - & - & - & - & - & - & - & 一 & - & - & - \\
\hline Autoradiography & 513 & 30.4 & 0.022 & 4.8 & 0.000 & 9.9 & 0.000 & 64.7 & 0.032 & 3.5 & - & - & - & - & - \\
\hline Blot washing & 89 & 42.7 & 0.004 & - & - & 44.9 & 0.004 & 92.1 & 0.002 & 7.9 & 0.004 & - & - & $\rightarrow$ & - \\
\hline Cancer treatment & - & - & - & - & - & - & - & - & - & - & - & - & - & - & - \\
\hline Cell assays & 35 & 61.3 & 0.073 & 2.8 & 0.000 & - & - & 38.7 & 0.221 & - & - & - & - & - & - \\
\hline Cell culture labeling & 1,842 & 85.6 & 0.134 & 9.2 & 0.026 & 6.8 & 0.023 & 16.6 & 0.088 & 8.1 & 0.013 & - & - & - & - \\
\hline Deprobing membranes & 154 & 93.5 & 0.000 & - & - & - & - & 16.9 & 0.000 & - & - & - & - & - & - \\
\hline DNA/RNA extractions/sequencing & 729 & 39.8 & 0.058 & 6.6 & 0.009 & 8.3 & 0.004 & 60.6 & 0.020 & - & - & - & - & - & - \\
\hline Electron microscopy & 29 & - & - & - & - & - & - & - & - & - & - & - & - & 100.0 & 0.000 \\
\hline Electrophoresis & 101 & 19.8 & 0.000 & 19.8 & 0.001 & 15.8 & 0.002 & 62.4 & 0.064 & 17.8 & 0.001 & - & - & - & - \\
\hline Equipment cleaning & 97 & 83.5 & 0.393 & 16.5 & 0.015 & - & - & 20.6 & 0.183 & - & - & - & - & - & - \\
\hline Filter washes & 3,798 & 72.1 & 0.110 & 10.6 & 0.025 & 11.2 & 0.022 & 30.9 & 0.041 & 1.1 & 0.001 & - & - & - & - \\
\hline Gel fixing/washing & 9,721 & 20.0 & 0.127 & 3.4 & 0.004 & 16.2 & 0.005 & 80.3 & 0.031 & 5.6 & 0.003 & - & - & - & - \\
\hline Hormonal labeling & 30 & 40.0 & 0.000 & 60.0 & 0.000 & - & - & - & - & - & - & - & - & - & - \\
\hline HPLC scintillation counting & 616 & 85.4 & 0.176 & 1.3 & 0.002 & 7.1 & 0.102 & 23.0 & 0.394 & 11.5 & 0.011 & - & 一 & - & - \\
\hline Lipid extraction & 72 & 97.2 & 0.783 & 25.0 & 0.151 & - & - & - & - & - & - & - & - & - & - \\
\hline Membrane washing & 17 & 100.0 & 0.104 & - & - & - & - & - & - & - & - & - & - & - & - \\
\hline One-time processes & 512 & 68.2 & 0.033 & 7.8 & 0.076 & 5.1 & 0.018 & 27.9 & 0.069 & 1.6 & 0.001 & - & - & 3.1 & 0.123 \\
\hline Operating room wastes & - & - & - & - & - & - & - & - & - & - & - & - & - & - & - \\
\hline Perfusion fixation & 110 & 45.5 & 0.016 & - & - & 3.6 & - & 3.6 & - & 16.4 & 0.001 & - & - & 一 & - \\
\hline Phosphorylation & 24 & 16.7 & 0.000 & - & - & - & - & 83.3 & 0.000 & - & - & - & - & - & - \\
\hline Protein harvesting & 5 & - & - & - & - & - & - & 11.1 & 2.120 & 88.9 & 0.000 & - & - & - & - \\
\hline Protein precipitation & 455 & 81.3 & 0.292 & 11.0 & 0.004 & 6.6 & 0.044 & 35.9 & 0.021 & 4.4 & 0.007 & - & - & - & - \\
\hline Radioassay & 562 & 65.6 & 0.326 & 39.4 & 0.020 & 0.1 & 0.000 & 8.2 & 0.004 & 3.5 & 0.087 & - & - & - & - \\
\hline Radioimmunoassay & 124 & 61.3 & 0.246 & - & - & 16.1 & 0.003 & 45.2 & 0.154 & 51.6 & 0.001 & - & - & - & - \\
\hline Reverse transcriptase Assays & 670 & 100.0 & 0.155 & - & - & - & - & - & - & - & - & - & - & - & - \\
\hline Silver staining & 306 & 61.4 & 0.001 & - & - & 44.4 & 0.006 & 19.0 & 0.013 & - & - & - & - & - & - \\
\hline Staining/destaining & 45 & 18.0 & 0.006 & - & - & 80.9 & 0.002 & 82.0 & 0.004 & - & - & - & - & - & - \\
\hline Tissue assay & 103 & 61.5 & 0.107 & 20.3 & 0.025 & - & - & 31.2 & 0.024 & - & - & - & - & - & - \\
\hline
\end{tabular}


Table 5-4. (continued).

\begin{tabular}{|c|c|c|c|c|c|c|c|c|c|c|c|c|c|c|c|}
\hline \multirow[b]{2}{*}{ Waste generating process } & \multirow[b]{2}{*}{$\begin{array}{c}\text { Waste } \\
\text { volume } \\
\text { (L) }\end{array}$} & \multicolumn{2}{|c|}{$3_{\mathrm{H}}$} & \multicolumn{2}{|c|}{${ }^{14} \mathrm{C}$} & \multicolumn{2}{|c|}{${ }^{32} \mathrm{P}$} & \multicolumn{2}{|c|}{${ }^{35} \mathrm{~s}$} & \multicolumn{2}{|c|}{$125_{I}$} & \multicolumn{2}{|c|}{${ }^{131_{I}}$} & \multicolumn{2}{|c|}{${ }^{238}{ }_{\mathrm{U}}$} \\
\hline & & $\begin{array}{c}\% \text { of } \\
\text { volume }\end{array}$ & $\begin{array}{l}\text { Average } \\
\text { activity } \\
(\mathrm{mCi} / \mathrm{L})\end{array}$ & $\begin{array}{c}\% \text { of } \\
\text { volume }\end{array}$ & $\begin{array}{l}\text { Average } \\
\text { activity } \\
\text { (mCi } / \text { ) }\end{array}$ & $\begin{array}{l}\% \text { of } \\
\text { volume }\end{array}$ & $\begin{array}{c}\text { Average } \\
\text { activity } \\
(\mathrm{mCi} / \mathrm{L})\end{array}$ & $\begin{array}{l}\% \text { of } \\
\text { volume }\end{array}$ & $\begin{array}{l}\text { Average } \\
\text { activity } \\
(\mathrm{mCi} / \mathrm{L})\end{array}$ & $\begin{array}{c}\% \text { of } \\
\text { volume }\end{array}$ & $\begin{array}{l}\text { Average } \\
\text { activity } \\
\text { (mCi/L) }\end{array}$ & $\begin{array}{c}\% \text { of } \\
\text { volume }\end{array}$ & $\begin{array}{c}\text { Average } \\
\text { activity } \\
(\mathrm{mCl} / \mathrm{L})\end{array}$ & $\begin{array}{c}\% \text { of } \\
\text { volume }\end{array}$ & $\begin{array}{l}\text { Average } \\
\text { activity } \\
\text { (mCi/L) }\end{array}$ \\
\hline Tissue staining & 35 & - & - & - & - & 54.3 & 0.008 & 100.0 & 0.020 & - & - & - & - & - & - \\
\hline Unknown & 735 & 67.1 & 0.097 & 7.5 & 0.223 & 12.9 & 0.001 & 25.3 & 0.177 & 5.8 & 0.000 & - & - & 2.7 & 0.000 \\
\hline
\end{tabular}


Table 5-5. Chemical properties of NIH mixed waste in process.

\begin{tabular}{|c|c|c|c|c|}
\hline Waste generating process & $\begin{array}{c}\text { Waste } \\
\text { volume } \\
\text { (L) }\end{array}$ & $\underset{\text { minimum }}{\mathrm{pH}}$ & $\underset{\text { maximum }}{\mathrm{pH}}$ & $\begin{array}{l}\text { Flashpoint } \\
\text { minimum } \\
\left.{ }^{\circ}{ }^{\circ} \mathrm{F}\right)\end{array}$ \\
\hline ATP extractions & 56 & 1.6 & 1.8 & 96 \\
\hline Automated amino assay & 0 & N/A & N/A & N/A \\
\hline Autoradiography & 103 & 0.2 & 3.8 & 84 \\
\hline Blot washing & 0 & N/A & N/A & N/A \\
\hline Cancer treatment & 101 & N/A & N/A & N/A \\
\hline Cell assays & 10 & N/A & N/A & N/A \\
\hline Cell culture labeling & 560 & 0.1 & 4.7 & 83 \\
\hline Deprobing membranes & 0 & N/A & N/A & N/A \\
\hline DNA/RNA extractions/sequencing & 422 & 1.2 & 8.9 & 75 \\
\hline Electron microscopy & 317 & 2.1 & 8.0 & 139 \\
\hline Electrophoresis & 40 & 0.9 & 8.0 & 80 \\
\hline Equipment cleaning & 32 & 2.8 & 7.4 & 90 \\
\hline Filter washes & 394 & 0.4 & 8.4 & 65 \\
\hline Gel fixing/washing & 2,193 & 0.1 & 7.8 & 76 \\
\hline Hormonal labeling & 0 & N/A & N/A & N/A \\
\hline HPLC scintillation counting & 2,188 & 0.5 & 9.2 & 65 \\
\hline Lipid extraction & 16 & 2.4 & 2.4 & 86 \\
\hline Membrane washing & 1 & 1.0 & 1.0 & 141 \\
\hline One-time processes & 766 & 3.9 & 7.6 & 99 \\
\hline Operating room wastes & 81 & N/A & N/A & N/A \\
\hline Perfusion fixation & 55 & 4.5 & 7.1 & 105 \\
\hline Phosphorylation & 26 & 1.0 & 1.9 & 141 \\
\hline Protein harvesting & 8 & 1.7 & 1.7 & 95 \\
\hline Protein precipitation & 347 & 0.1 & 6.8 & 139 \\
\hline Radioassay & 647 & 1.0 & 8.7 & 63 \\
\hline Radioimmunoassay & 17 & 6.7 & 6.7 & 99 \\
\hline Reverse transcriptase assays & 40 & 0.7 & 1.6 & 141 \\
\hline Silver staining & 52 & 3.8 & 9.7 & 99 \\
\hline Staining/destaining & 247 & 0.1 & 3.2 & 92 \\
\hline Tissue assay & 10 & 6.7 & 6.7 & 141 \\
\hline Tissue staining & 38 & 5.4 & 5.9 & 138 \\
\hline Unknown & 1,122 & 0.5 & 8.6 & 58 \\
\hline
\end{tabular}


Table 5-6. Chemicals typically present in NIH mixed waste in process.

Volume percent of waste with chemicals present

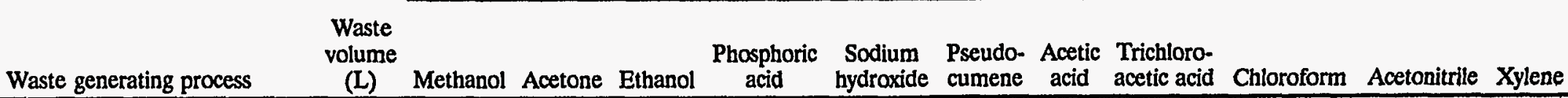

ATP extractions

Automated amino assay

Autoradiography

Blot washing

Cancer treatment

Cell assays

Cell culture labeling

Deprobing membranes

DNA/RNA extractions/sequencing

$\begin{array}{lll}56 & 100.0 \quad 100.0\end{array}$

Electron microscopy

Electrophoresis

Equipment cleaning

in Filter washes

Gel fixing/washing

Hormonal labeling

HPLC scintillation counting

Lipid extraction

Membrane washing

One-time processes

Operating room wastes

Perfusion fixation

Phosphorylation

Protein harvesting

Protein precipitation

Radioassay

Radioimmunoassay

Reverse transcriptase assays

Silver staining

\begin{tabular}{|c|c|c|c|}
\hline 56 & 100.0 & 100.0 & - \\
\hline- & - & - & - \\
\hline 103 & 27.2 & - & 0.5 \\
\hline- & - & - & - \\
\hline 101 & - & - & - \\
\hline 10 & - & - & - \\
\hline 560 & 14.7 & - & 5.9 \\
\hline- & - & - & - \\
\hline 422 & 68.7 & - & 0.2 \\
\hline 317 & - & - & 6.3 \\
\hline 40 & 99.5 & - & - \\
\hline 32 & 100.0 & 12.5 & - \\
\hline 394 & 34.8 & 5.1 & 5.1 \\
\hline 2,193 & 60.2 & 2.1 & 6.7 \\
\hline- & - & - & - \\
\hline 2,188 & 37.7 & 0.4 & 6.3 \\
\hline 16 & 100.0 & - & - \\
\hline 1 & - & - & - \\
\hline 766 & 0.2 & 2.1 & - \\
\hline 81 & - & - & - \\
\hline 55 & - & - & - \\
\hline 26 & - & - & 30.8 \\
\hline 8 & - & - & 100.0 \\
\hline 347 & - & 1.2 & 2.9 \\
\hline 647 & 1.5 & - & 4.3 \\
\hline 17 & - & - & 100.0 \\
\hline 40 & 50.0 & - & - \\
\hline 52 & 26.9 & - & 26.9 \\
\hline
\end{tabular}

\begin{tabular}{|c|c|}
\hline- & - \\
\hline- & - \\
\hline- & - \\
\hline- & - \\
\hline- & - \\
\hline- & - \\
\hline 3.4 & - \\
\hline- & - \\
\hline- & - \\
\hline- & - \\
\hline- & 49.8 \\
\hline- & - \\
\hline 11.2 & - \\
\hline 6.0 & - \\
\hline- & - \\
\hline 2.7 & - \\
\hline- & - \\
\hline- & - \\
\hline 2.5 & 2.5 \\
\hline- & - \\
\hline- & 61.8 \\
\hline 30.8 & - \\
\hline- & - \\
\hline- & - \\
\hline 6.2 & - \\
\hline- & - \\
\hline- & - \\
\hline & \\
\hline
\end{tabular}

\begin{tabular}{|c|c|c|}
\hline- & 100.0 & - \\
\hline- & - & - \\
\hline 19.5 & 25.1 & 19.5 \\
\hline- & - & - \\
\hline- & 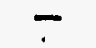 & - \\
\hline- & - & - \\
\hline- & 6.4 & 3.6 \\
\hline- & - & - \\
\hline- & 59.2 & 4.7 \\
\hline- & - & - \\
\hline- & 49.8 & - \\
\hline- & - & - \\
\hline- & 15.5 & 38.8 \\
\hline 0.5 & 54.2 & 7.4 \\
\hline- & - & - \\
\hline 45.4 & 7.6 & 1.8 \\
\hline- & - & - \\
\hline- & - & 100.0 \\
\hline 2.3 & 3.0 & - \\
\hline- & - & - \\
\hline- & - & - \\
\hline 一 & - & 69.2 \\
\hline- & - & 100.0 \\
\hline- & - & 23.1 \\
\hline- & 3.1 & 6.2 \\
\hline- & - & - \\
\hline- & - & 50.0 \\
\hline - & 26.9 & - \\
\hline
\end{tabular}

\begin{tabular}{|c|c|c|}
\hline- & - & - \\
\hline- & - & - \\
\hline 19.5 & - & - \\
\hline- & - & - \\
\hline- & - & - \\
\hline- & - & - \\
\hline 2.9 & - & - \\
\hline- & - & - \\
\hline 0.4 & - & - \\
\hline- & 4.1 & - \\
\hline- & - & - \\
\hline 25.0 & - & - \\
\hline 18.3 & - & - \\
\hline 2.9 & - & - \\
\hline- & $\rightarrow$ & - \\
\hline 1.6 & 11.5 & 5.4 \\
\hline 100.0 & - & - \\
\hline - & - & - \\
\hline - & - & - \\
\hline - & - & - \\
\hline - & - & $T$ \\
\hline- & - & - \\
\hline- & - & - \\
\hline 9.2 & - & - \\
\hline 2.8 & - & - \\
\hline- & 100.0 & - \\
\hline- & - & - \\
\hline- & - & - \\
\hline
\end{tabular}


Table 5-6. (continued).

\begin{tabular}{|c|c|c|c|c|c|c|c|c|c|c|c|c|}
\hline \multirow[b]{2}{*}{ Waste generating process } & \multirow[b]{2}{*}{$\begin{array}{c}\text { Waste } \\
\text { volume } \\
\text { (L) }\end{array}$} & \multicolumn{11}{|c|}{ Volume percent of waste with chemicals present } \\
\hline & & Methanol & Acetone & Ethanol & $\begin{array}{l}\text { Phosphoric } \\
\text { acid }\end{array}$ & $\begin{array}{c}\text { Sodium } \\
\text { hydroxide }\end{array}$ & $\begin{array}{l}\text { Pseudo- } \\
\text { cumene }\end{array}$ & $\begin{array}{l}\text { Acetic } \\
\text { acid }\end{array}$ & $\begin{array}{l}\text { Trichloro- } \\
\text { acetic acid }\end{array}$ & Chloroform & Acetonitrile & Xylene \\
\hline Staining/destaining & 247 & 3.2 & 65.6 & - & 11.3 & - & - & 4.9 & - & - & - & - \\
\hline Tissue assay & 10 & - & - & - & - & - & - & - & - & - & - & - \\
\hline Tissue staining & 38 & - & - & - & - & - & - & - & - & - & - & - \\
\hline Unknown & 1,122 & 18.8 & 1.8 & 1.1 & 0.4 & 0.7 & 1.8 & 9.9 & 2.5 & 2.7 & 3.2 & - \\
\hline
\end{tabular}

Note: A blank indicates the specified waste parameter is not applicable to the indicated waste generating process. 
Table 5-7. Typical EPA hazardous waste numbers for NIH mixed waste in process.

\begin{tabular}{lrrrrrrrrrrr} 
& Waste & \multicolumn{7}{c}{ Volume percent of waste using EPA hazardous waste number } \\
\cline { 3 - 9 } \multicolumn{1}{c}{ Waste generating process } & $\begin{array}{c}\text { volum } \\
\text { (L) }\end{array}$ & D001 & D002 & D007 & D008 & D011 & D022 & F001 & F003 & F005 \\
\hline ATP extractions & 56 & 100 & 100 & - & - & - & - & - & 100 & 68 \\
Automated amino assay & - & - & - & - & - & - & - & - & - & - \\
Autoradiography & 103 & 80 & 47 & - & - & - & 19 & - & 47 & - \\
Blot washing & - & - & - & - & - & - & - & - & - & - \\
Cancer treatment & 101 & - & - & - & - & - & - & - & - & - \\
Cell assays & 10 & - & - & - & - & - & - & - & - & - \\
Cell culture labeling & 560 & 24 & 21 & - & - & - & 3 & - & 18 & - \\
Deprobing membranes & - & - & - & - & - & - & - & - & - & - \\
DNA/RNA extractions/sequencing & 422 & 55 & 18 & - & - & - & 0 & - & 64 & - \\
Electron microscopy & 317 & 4 & 0 & - & 45.7 & - & - & - & - & - \\
Electrophoresis & 40 & 50 & 50 & - & - & - & - & - & 100 & - \\
Equipment cleaning & 32 & 100 & - & - & - & - & 25 & - & 100 & - \\
Filter washes & 394 & 6 & 51 & - & - & - & 39 & - & 21 & - \\
Gel fixing/washing & 2,193 & 51 & 27 & - & - & - & 9 & - & 55 & - \\
Hormonal labeling & - & - & - & - & - & - & - & - & - & - \\
HPLC scintillation counting & 2,188 & 82 & 15 & - & - & - & 3 & - & 49 & 1 \\
Lipid extraction & 16 & 13 & - & - & - & - & 13 & - & 13 & - \\
Membrane washing & 1 & - & 100 & - & - & - & 100 & - & - & - \\
One-time processes & 766 & 6 & - & - & 0.8 & - & - & - & 1 & 3 \\
Operating room wastes & 81 & - & - & - & - & - & - & - & - & - \\
Perfusion fixation & 55 & 36 & - & - & - & - & - & - & - & - \\
Phosphorylation & 26 & - & 100 & - & - & - & 69 & - & - & - \\
Protein harvesting & 8 & 100 & 100 & - & - & - & - & - & - & - \\
Protein precipitation & 347 & 1 & 17 & - & - & - & 15 & - & 1 & - \\
Radioassay & 647 & 9 & 6 & - & - & - & 9 & - & 2 & 3
\end{tabular}


Table 5-7. (continued).

\begin{tabular}{|c|c|c|c|c|c|c|c|c|c|c|}
\hline \multirow[b]{2}{*}{ Waste generating process } & \multirow{2}{*}{$\begin{array}{c}\text { Waste } \\
\text { volume } \\
\text { (L) }\end{array}$} & \multicolumn{9}{|c|}{ Volume percent of waste using EPA hazardous waste number } \\
\hline & & D001 & DO02 & $\mathrm{D} 007$ & D008 & D011 & D022 & F001 & FO03 & FoOS \\
\hline Radioimmunoassay & 17 & 100 & - & - & - & - & - & - & - & - \\
\hline Reverse transcriptase assays & 40 & - & 100 & - & - & - & - & - & 50 & - \\
\hline Silver staining & 52 & 65 & - & - & - & 34.6 & - & - & 27 & - \\
\hline Staining/destaining & 247 & 5 & 3 & - & - & - & - & - & 3 & - \\
\hline Tissue assay & 10 & - & - & - & - & - & - & - & - & - \\
\hline Tissue staining & 38 & - & - & - & 68.4 & - & - & - & - & - \\
\hline Unknown & 1,122 & 18 & 5 & - & - & - & 3 & - & 19 & 1 \\
\hline
\end{tabular}

Note: A blank indicates the specified waste parameter is not applicable to the indicated waste generating process. 
Table 5-8. Radiological properties of NIH mixed waste in process.

\begin{tabular}{|c|c|c|c|c|c|c|c|c|c|c|c|c|c|c|c|}
\hline \multirow[b]{2}{*}{ Waste generating process } & \multirow[b]{2}{*}{$\begin{array}{c}\text { Waste } \\
\text { volume } \\
\text { (L) }\end{array}$} & \multicolumn{2}{|c|}{$3_{\mathrm{H}}$} & \multicolumn{2}{|c|}{${ }^{14} \mathrm{C}$} & \multicolumn{2}{|c|}{$32_{\mathrm{P}}$} & \multicolumn{2}{|c|}{${ }^{35} \mathrm{~S}$} & \multicolumn{2}{|c|}{$125_{I}$} & \multicolumn{2}{|c|}{${ }^{131_{I}}$} & \multicolumn{2}{|c|}{${ }^{238} 8_{U}$} \\
\hline & & $\begin{array}{l}\% \text { of } \\
\text { volume }\end{array}$ & $\begin{array}{l}\text { Average } \\
\text { activity } \\
\text { (mCi/L) }\end{array}$ & $\begin{array}{c}\% \text { of } \\
\text { volume }\end{array}$ & $\begin{array}{l}\text { Average } \\
\text { activity } \\
\text { (mCi/L) }\end{array}$ & $\begin{array}{c}\% \text { of } \\
\text { volume }\end{array}$ & $\begin{array}{l}\text { Average } \\
\text { activity } \\
\text { (mCi/L) }\end{array}$ & $\begin{array}{c}\% \text { of } \\
\text { volume }\end{array}$ & $\begin{array}{l}\text { Average } \\
\text { activity } \\
\text { (mCi/L) }\end{array}$ & $\begin{array}{l}\% \text { of } \\
\text { volume }\end{array}$ & $\begin{array}{l}\text { Average } \\
\text { activity } \\
\text { (mCi/L) }\end{array}$ & $\begin{array}{c}\% \text { of } \\
\text { volume }\end{array}$ & $\begin{array}{l}\text { Average } \\
\text { activity } \\
\text { (mCi/L) }\end{array}$ & $\begin{array}{l}\% \text { of } \\
\text { volume }\end{array}$ & $\begin{array}{l}\text { Average } \\
\text { activity } \\
\text { (mCi/L) }\end{array}$ \\
\hline ATP extractions & 56 & - & - & - & - & 100.0 & 0.012 & - & - & - & - & - & - & - & - \\
\hline Automated amino assay & - & - & - & - & - & - & - & - & - & - & - & - & - & - & - \\
\hline Autoradiography & 103 & 1.5 & 0.020 & 19.5 & 0.000 & - & - & 79.1 & 0.012 & - & - & - & - & - & - \\
\hline Blot washing & - & - & - & - & - & - & - & - & - & - & - & - & - & - & - \\
\hline Cancer treatment & 101 & - & - & - & - & - & - & - & - & - & - & 100.0 & 0.085 & - & - \\
\hline Cell assays & 10 & 100.0 & 0.012 & - & - & - & - & 100.0 & 0.006 & - & - & - & - & - & - \\
\hline Cell culture labeling & 560 & 69.0 & 0.049 & 51.1 & 0.003 & 13.0 & 0.041 & 14.8 & 0.084 & - & - & - & - & - & - \\
\hline Deprobing membranes & - & - & - & - & - & - & - & - & - & - & - & - & - & - & - \\
\hline DNA/RNA extractions/sequencing & 422 & 7.6 & 0.397 & - & - & 35.5 & 0.009 & 69.2 & 0.013 & - & - & - & - & - & - \\
\hline Electron microscopy & 317 & 41.1 & 0.034 & 5.4 & 0.001 & - & - & 6.3 & 0.001 & - & - & - & - & 80.6 & 0.002 \\
\hline Electrophoresis & 40 & 50.2 & 0.017 & - & - & 99.5 & 0.041 & 49.8 & 0.015 & - & - & - & - & - & - \\
\hline Equipment cleaning & 32 & 87.5 & 0.242 & - & - & - & - & 12.5 & 0.025 & - & - & - & - & - & - \\
\hline Filter washes & 394 & 25.4 & 0.115 & 4.6 & 0.019 & 60.4 & 0.028 & 2.0 & 0.016 & 4.1 & 0.094 & - & - & - & - \\
\hline Gel fixing/washing & 2,193 & 15.0 & 0.072 & 1.0 & 0.005 & 43.9 & 0.024 & 25.4 & 0.074 & 2.4 & 0.015 & - & - & - & - \\
\hline Hormonal labeling & - & - & - & - & - & - & - & - & - & - & - & - & - & - & - \\
\hline HPLC scintillation counting & 2,188 & 67.0 & 0.030 & 15.8 & 0.003 & 2.7 & 0.002 & 14.8 & 0.014 & 4.8 & 0.003 & - & - & - & - \\
\hline Lipid extraction & 16 & 100.0 & 1.027 & - & - & 43.8 & 0.003 & - & - & - & - & - & - & - & - \\
\hline Membrane washing & 1 & - & - & - & - & 100.0 & 0.010 & - & - & - & - & - & - & - & - \\
\hline One-time processes. & 766 & 8.6 & 0.323 & 0.1 & 28.800 & 9.5 & 0.011 & 11.0 & 0.030 & 5.3 & 0.000 & - & - & - & - \\
\hline Operating room wastes & 81 & - & - & - & - & - & - & - & - & - & - & 100.0 & 0.087 & - & - \\
\hline Perfusion fixation & 55 & 69.1 & 0.000 & - & - & - & - & - & - & 30.9 & 0.003 & - & - & - & - \\
\hline Phosphorylation & 26 & - & - & - & - & 100.0 & 0.006 & - & - & - & - & - & - & - & - \\
\hline Protein harvesting & 8 & $\cdot 100.0$ & 0.005 & - & - & - & - & - & - & - & - & - & - & - & - \\
\hline Protein precipitation & 347 & $\cdot 34.3$ & 0.339 & - & - & 19.6 & 0.493 & 7.5 & 0.168 & 5.8 & 0.032 & - & - & - & - \\
\hline Radioassay & 647 & 86.9 & 0.082 & 9.3 & 0.023 & 6.8 & 0.018 & 78.2 & 0.000 & - & - & - & - & - & - \\
\hline Radioimmunoassay & 17 & - & - & - & - & - & - & - & - & 100.0 & 0.004 & - & - & - & - \\
\hline Reverse transcriptase assays & 40 & 100.0 & 0.227 & - & - & - & - & - & - & - & - & - & - & - & - \\
\hline Silver staining & 52 & 38.5 & 0.003 & - & - & 100.0 & 0.001 & - & - & - & - & - & - & - & - \\
\hline
\end{tabular}


Table 5-8. (continued).

\begin{tabular}{|c|c|c|c|c|c|c|c|c|c|c|c|c|c|c|c|}
\hline \multirow[b]{2}{*}{ Waste generating process } & \multirow[b]{2}{*}{$\begin{array}{c}\text { Waste } \\
\text { volume } \\
\text { (L) }\end{array}$} & \multicolumn{2}{|c|}{$3_{H}$} & \multicolumn{2}{|c|}{${ }^{14} \mathrm{C}$} & \multicolumn{2}{|c|}{${ }^{32} P$} & \multicolumn{2}{|c|}{${ }^{35} \mathrm{~S}$} & \multicolumn{2}{|c|}{$125_{I}$} & \multicolumn{2}{|c|}{$131_{1}$} & \multicolumn{2}{|c|}{${ }^{238} \mathrm{U}$} \\
\hline & & $\begin{array}{l}\% \text { of } \\
\text { volume }\end{array}$ & $\begin{array}{l}\text { Average } \\
\text { activity } \\
\text { (mCi/L) }\end{array}$ & $\begin{array}{l}\% \text { of } \\
\text { volume }\end{array}$ & $\begin{array}{l}\text { Average } \\
\text { activity } \\
\text { (mCi/L) }\end{array}$ & $\begin{array}{c}\% \text { of } \\
\text { volume }\end{array}$ & $\begin{array}{l}\text { Average } \\
\text { activity } \\
\text { (mCi/L) }\end{array}$ & $\begin{array}{c}\% \text { of } \\
\text { volume }\end{array}$ & $\begin{array}{l}\text { Average } \\
\text { activity } \\
\text { (mCi/L) }\end{array}$ & $\begin{array}{c}\% \text { of } \\
\text { volume }\end{array}$ & $\begin{array}{l}\text { Average } \\
\text { activity } \\
\text { (mCiL) }\end{array}$ & $\begin{array}{l}\% \text { of } \\
\text { volume }\end{array}$ & $\begin{array}{l}\text { Average } \\
\text { activity } \\
\text { (mCi/L) }\end{array}$ & $\begin{array}{l}\text { \% of } \\
\text { volume }\end{array}$ & $\begin{array}{l}\text { Average } \\
\text { activity } \\
\text { (mCi/L) }\end{array}$ \\
\hline Staining/destaining & 247 & 66.5 & 0.388 & - & - & 28.3 & 0.036 & 19.8 & 0.271 & 8.1 & 0.065 & - & - & - & - \\
\hline Tissue assay & 10 & - & - & - & - & - & - & - & - & 100.0 & 0.009 & - & - & - & - \\
\hline Tissue staining & 38 & - & - & - & - & - & - & - & - & - & - & - & - & 68.4 & 0.000 \\
\hline Unknown & 1,122 & 69.1 & 0.064 & 48.9 & 0.001 & 19.8 & 0.012 & 14.7 & 0.012 & 2.6 & 0.005 & - & - & 2.3 & 0.000 \\
\hline
\end{tabular}

Note: A blank indicates the specified waste parameter is not applicable to the indicated waste generating process. 
Table 5-9 presents a summary by process of the overall waste stream, waste disposed of, waste in process, and waste with no disposal options. As can be seen, approximately one-third of the overall waste stream has no disposal options. About $15 \%$ of the overall waste stream exists as waste in process and slightly over one-half of the waste has been disposed of using one of the disposal options available. Figures 5-1, 5-2, and 5-3 graphically depict the distribution of the waste streams by process category. Generally, gel fixing/washing and filter washes produce the largest proportionate volume of wastes with no disposal options. In coñtrast, HPLC scintillation counting wastes genèrally have disposal options availàble. 
Table 5-9. Volume of NIH mixed waste by handling steps.

\begin{tabular}{|c|c|c|c|c|c|c|c|}
\hline \multirow[b]{2}{*}{ Waste generating process } & \multirow{2}{*}{$\begin{array}{c}\text { Total waste } \\
\text { received by NIH } \\
\text { (L) }\end{array}$} & \multicolumn{2}{|c|}{ Waste disposed } & \multicolumn{2}{|c|}{ Waste in process } & \multicolumn{2}{|c|}{$\begin{array}{l}\text { Waste with no disposal } \\
\text { options }\end{array}$} \\
\hline & & (L) & $\begin{array}{l}\text { Percent of } \\
\text { received volume }\end{array}$ & (L) & $\begin{array}{l}\text { Percent of } \\
\text { received volume }\end{array}$ & (L) & $\begin{array}{l}\text { Percent of } \\
\text { received volume }\end{array}$ \\
\hline ATP extractions & 56 & 0 & N/A & 56 & 100.0 & 0 & N/A \\
\hline Automated amino assay & 12 & 12 & 100.0 & 0 & N/A & $\mathbf{0}$ & N/A \\
\hline Autoradiography & 852 & 236 & 27.7 & 103 & 12.1 & 513 & 60.2 \\
\hline Blot washing & 349 & 260 & 74.5 & 0 & N/A & 89 & 25.5 \\
\hline Cancer treatment & 101 & 0 & N/A & 101 & 100.0 & 0 & N/A \\
\hline Cell assays & 95 & 50 & 52.6 & 10 & 10.5 & 35 & 36.9 \\
\hline Cell culture labeling & 3,913 & 1,511 & 38.6 & 560 & 14.3 & 1,842 & 47.1 \\
\hline Deprobing membranes & 1,209 & 1,055 & 87.3 & 0 & N/A & 154 & 12.7 \\
\hline DNA/RNA extractions/sequencing & 1,793 & 642 & 35.8 & 422 & 23.5 & 729 & 40.7 \\
\hline Electron microscopy & 601 & 256 & 42.5 & 317 & 52.7 & 29 & 4.8 \\
\hline Electrophoresis & 223 & 82 & 36.7 & 40 & 18.0 & 101 & 45.3 \\
\hline Equipment cleaning & 344 & 215 & 62.4 & 32 & 9.3 & 97 & 28.2 \\
\hline Filter washes & 8,261 & 4,069 & 49.3 & 394 & 4.8 & 3,798 & 46.0 \\
\hline Gel fixing/washing & 18,201 & 6,287 & 34.5 & 2,193 & 12.0 & 9,721 & 53.4 \\
\hline Hormonal labeling & 31 & 1 & 2.0 & 0 & N/A & 30 & 98.0 \\
\hline HPLC scintillation counting & 16,614 & 13,810 & 83.1 & 2,188 & 13.2 & 616 & 3.7 \\
\hline Lipid extraction & 88 & 0 & N/A & 16 & 18.2 & 72 & 81.8 \\
\hline Membrane washing & 42 & 24 & 57.8 & 1 & 1.2 & 17 & 41.0 \\
\hline One-time processes & 1,652 & 374 & 22.7 & 766 & 46.4 & 512 & 31.0 \\
\hline Operating room wastes & 156 & 75 & 48.3 & 81 & 51.7 & 0 & N/A \\
\hline Perfusion fixation & 453 & 288 & 63.6 & 55 & 12.1 & 110 & 24.3 \\
\hline Phosphorylation & 50 & 0 & N/A & 26 & 52.0 & 24 & 48.0 \\
\hline Protein harvesting & 34 & 21 & 62.7 & 8 & 23.9 & 5 & 13.4 \\
\hline Protein precipitation & 1,010 & 208 & 20.6 & 347 & 34.4 & 455 & 45.0 \\
\hline
\end{tabular}


Table 5-9. (continued).

\begin{tabular}{|c|c|c|c|c|c|c|c|}
\hline \multirow[b]{2}{*}{ Waste generating process } & \multirow{2}{*}{$\begin{array}{c}\text { Total waste } \\
\text { received by NIH } \\
\text { (L) }\end{array}$} & \multicolumn{2}{|c|}{ Waste disposed } & \multicolumn{2}{|c|}{ Waste in process } & \multicolumn{2}{|c|}{$\begin{array}{c}\text { Waste with no disposal } \\
\text { options }\end{array}$} \\
\hline & & (L) & $\begin{array}{l}\text { Percent of } \\
\text { received volume }\end{array}$ & (L) & $\begin{array}{l}\text { Percent of } \\
\text { received volume }\end{array}$ & (L) & $\begin{array}{l}\text { Percent of } \\
\text { received volume }\end{array}$ \\
\hline Radioassay & 1,344 & 135 & 10.0 & 647 & 48.1 & 562 & 41.8 \\
\hline Radioimmunoassay & 161 & 20 & 12.4 & 17 & 10.6 & 124 & 77.0 \\
\hline Reverse transcriptase assays & 990 & 280 & 28.3 & 40 & 4.0 & 670 & 67.7 \\
\hline Silver staining & 508 & 150 & 29.5 & 52 & 10.2 & 306 & 60.2 \\
\hline Staining/destaining & 292 & 0 & N/A & 247 & 84.7 & 45 & 15.3 \\
\hline Tissue assay & 223 & 110 & 49.3 & 10 & 4.5 & 103 & 46.2 \\
\hline Tissue staining & 149 & 76 & 50.8 & 38 & 25.6 & 35 & 23.6 \\
\hline Unknown & 4,342 & 2,485 & 57.2 & 1,122 & 25.8 & 735 & 16.9 \\
\hline Total & 64,146 & 32,730 & 51.0 & 9,887 & 15.4 & 21,529 & 33.6 \\
\hline
\end{tabular}


$6 \mathrm{I}-\mathrm{S}$

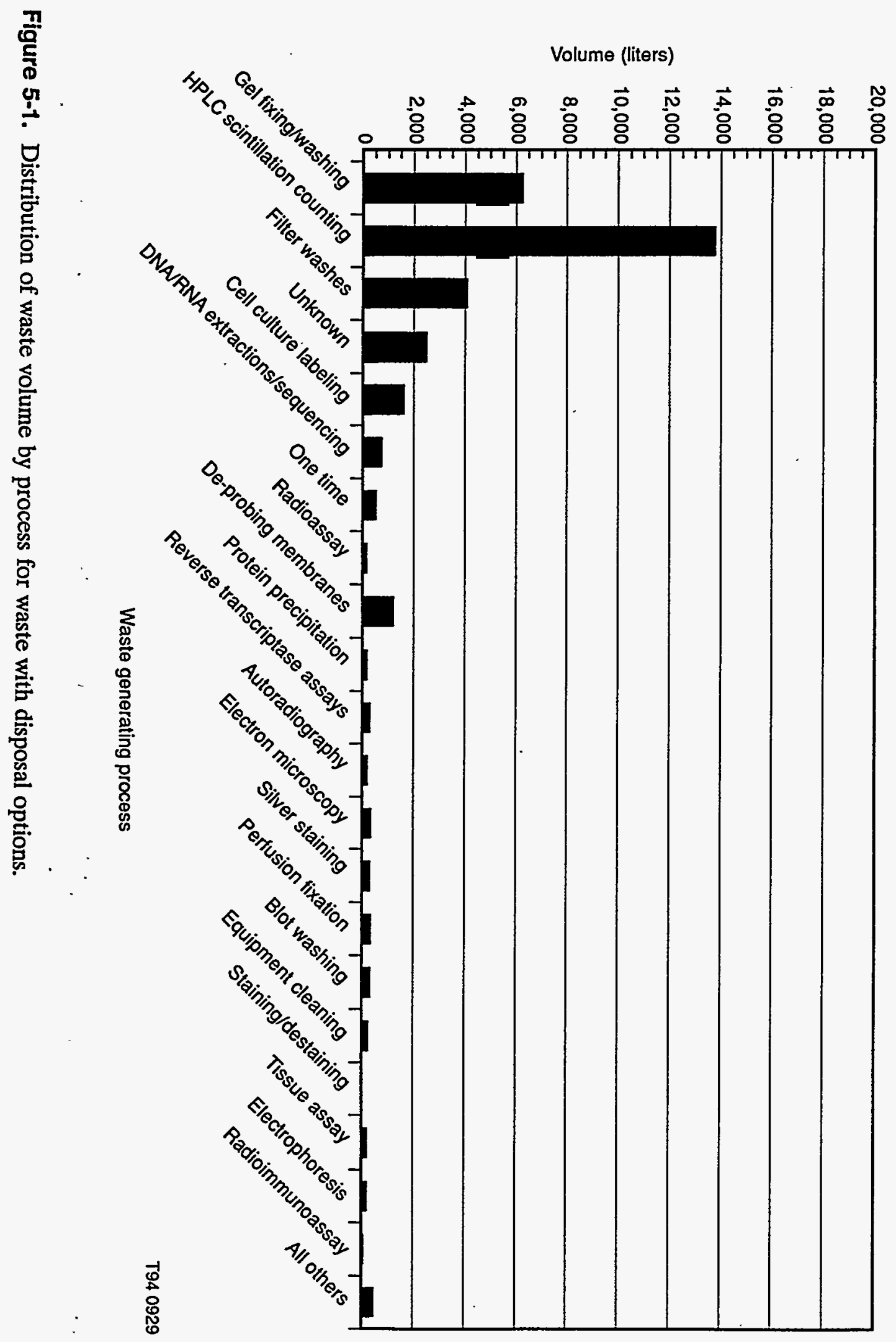




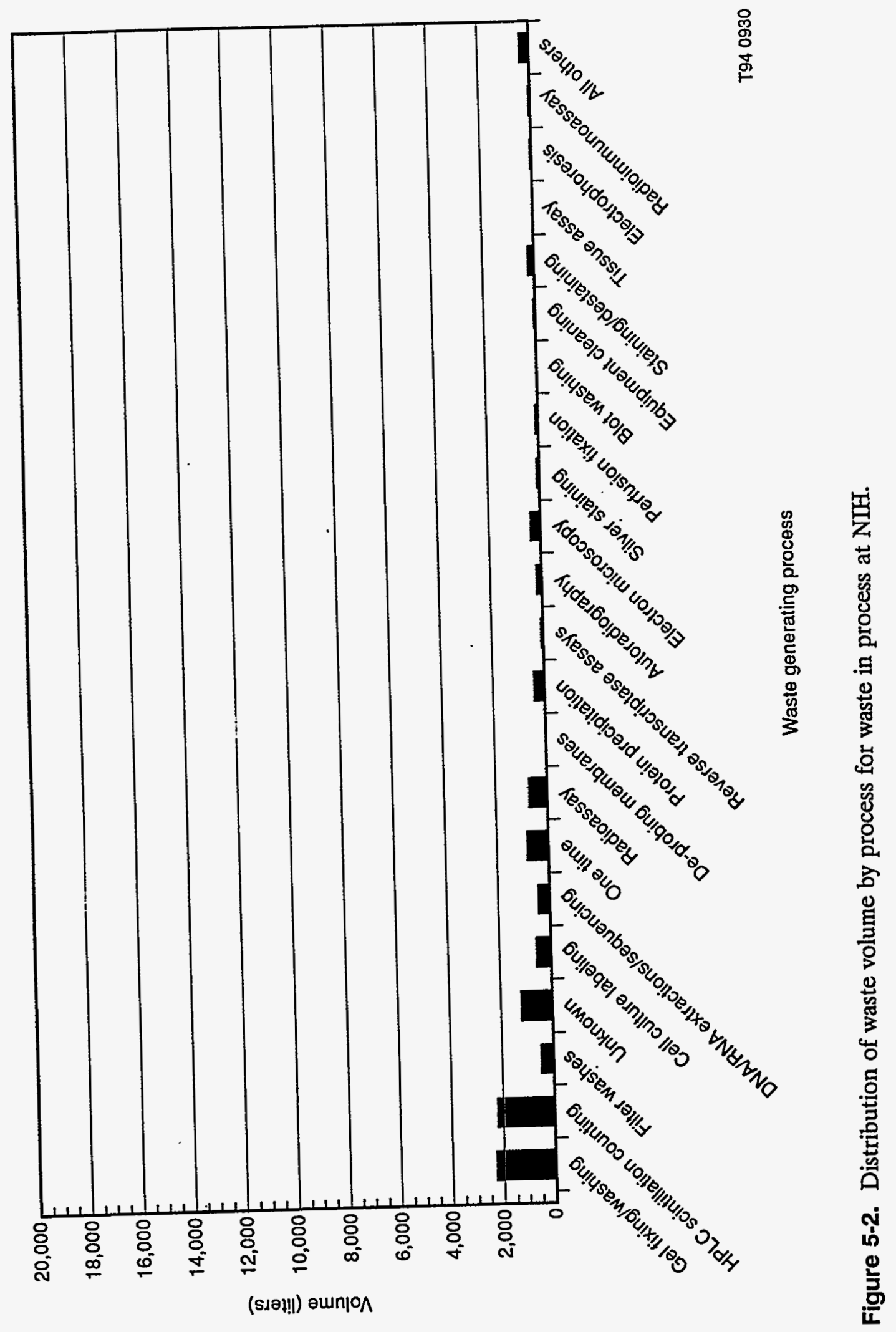




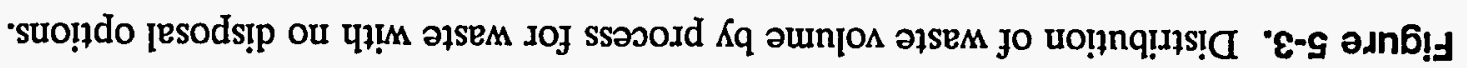

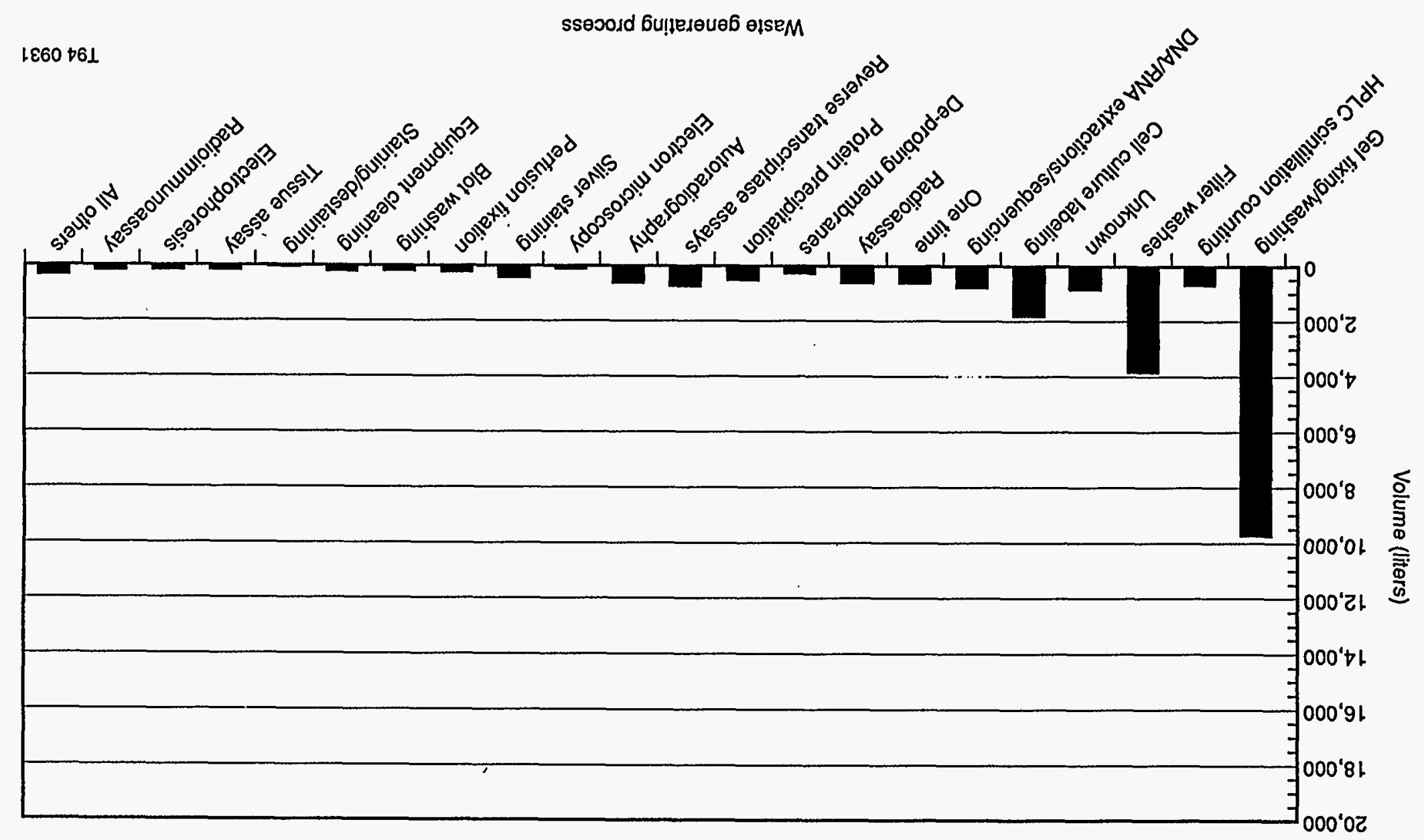




\section{CONCLUSIONS}

Section 2 of this report presents the results of the study in which the NIH wastes were combined into similar process groups. The results of this procedure reveal two significant findings: (a) relatively few waste generating processes produced the large majority of the mixed wastes, and (b) waste produced by these processes has relatively similar properties and compositions. In Section 3, it can be seen that a relatively small percentage (2.8\%) of the total containerized mixed waste volume shown in Table 2-1 can be attributed to one-time processes. The detailed characterization information presented in Sections 4 and 5 provides a valuable insight into the chemical and radiological properties of the waste based on the waste generating processes from which it was generated. This information provides a unique picture of biomedical mixed wastes. Figures 5-1, 5-2, and 5-3 are particularly helpful in pointing out areas upon which waste minimization efforts might profitably focus. These figures show that the majority of the waste with no disposal options is generated by the gel fixing/washing process group. To a lesser extent, the filter washing group also generates a large portion of the waste with no disposal options. The remaining process groups are almost insignificant in their waste generation volume by comparison with these processes.

The two supplemental mixed waste streams constitute approximately $96 \%$ by volume of the total waste volumes listed in Tables 2-1 and 2-2. The relatively large volume of these waste streams makes them candidates for waste minimization efforts. However, disposal options currently exist for these waste streams and they are not presently being accumulated onsite.

This report presents a review of the available data regarding mixed waste generation at the NIH. A follow-on study will be conducted to fully characterize waste generating processes. Specifically, individual NIH mixed waste generators will be interviewed to gain an in-depth understanding of the processes and analytical techniques that generate the waste stream and of the chemicals used. The goal of the analysis will be to identify potential changes in procedures and materials that would reduce the volume of mixed waste with no disposal options without sacrificing the quality of the research activities. 


\section{REFERENCES}

Dyer, A, Liquid Scintillation Counting Practice, Heyden \& Son Ltd., 1980.

Fini, C., A. Floridi, V. Finelli, and B. Wittman-Liebold, Laboratory Methodology in Biochemistry, CRC Press, 1990.

White, A., P. Handler, and E. Smith, Principles of Biochemistry, McGraw-Hill, Inc., 5th Edition, 1973.

Wang, Y., editor, Handbook of Radionuclides, CRC Press, 1969. 


\section{CONTACTS}

For additional information please contact:

Mr. Edward H. Rau

Chief, Hazardous and Solid Waste Management Section

Environmental Protection Branch

Division of Safety

National Institutes of Health

Building 13, Room $2 \mathrm{E} 63$

Bethesda, MD 20892

Phone: (301) 496-7990

Fax: (301) 480-8056

or

Mr. Sean M. Austin

Chief, Radioactive Materials Control Section

Radiation Safety Branch

Division of Safety

National Institutes of Health

Building 21, Room 104

Bethesda, MD 20892

Phone: (301) 496-5774

Fax: (301) 496-3544 